\title{
A REVISION OF THE COCCIDIA PARASITIC IN MAN.
}

\author{
By CLIFFORD DOBELL, F.R.S. \\ (Imperial College of Science.)
}

(With Plate VIII and 2 Text-figures.)

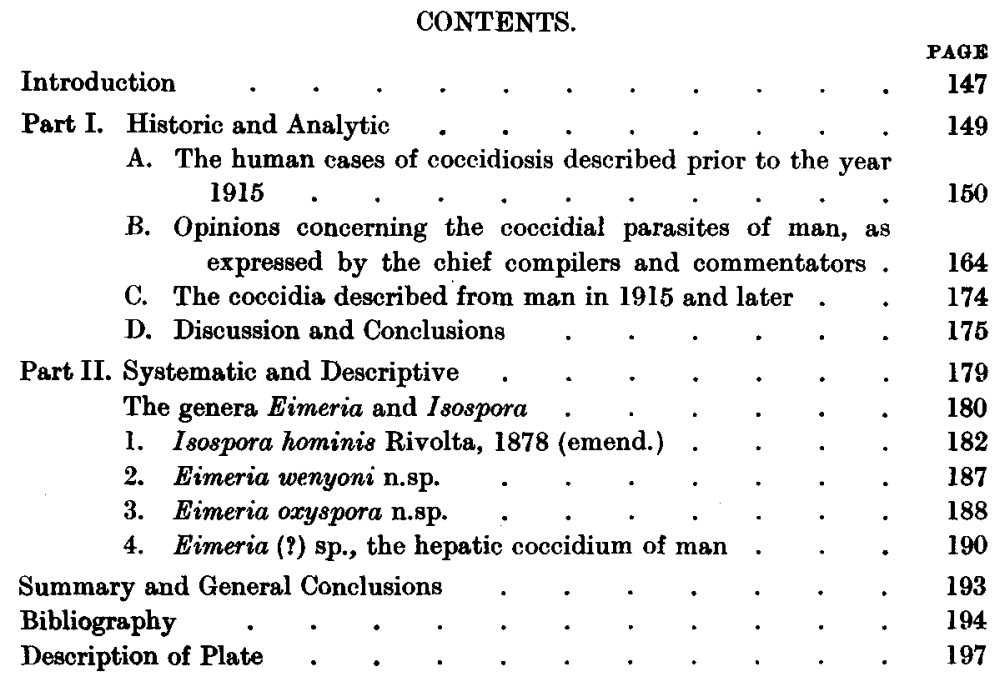

\section{INTRODUCTION.}

THE following memoir has grown gradually from very small beginnings until it has now assumed almost monographic proportions. Its history is as follows. Last year I accidentally discovered the oocyst of a coccidium in human faeces, and my attempts to identify it led me to study afresh the works of others dealing with the intestinal coccidia of man. From this I was led, little by little, to inquire into all the recorded cases of human coccidiosis which I could find. I had already studied this subject in some detail in the course of earlier work, and had perceived that our knowledge of the coccidial parasites of man was in a highly unsatisfactory condition; but I hardly realized, and I think few others even now fully realize, the state of decay into which it had fallen. Until the appearance of Wenyon's papers in 1915 hardly any facts had been definitely established concerning the coccidia of man; and the interpretations put upon such observations as had been recorded were - as can now, I think, be shown-for the most part wrong. But the new facts discovered by Wenyon have now made it possible to revise and correct our knowledge of the whole group of human parasites, and to place the organisms themselves on a secure 
systematic foundation. The pages which follow embody my attempts in this direction.

I have recently been able to read, or re-read, almost all the works dealing with the coccidia of man. This has been no small task, for much of the literature is difficult of access; and I infer, from what $I$ have read, that most people who have previously handled this subject have been deterred by this difficulty from consulting many of the original works. It is therefore almost superfluous to add that much of our "knowledge" has hitherto consisted of garbled versions of original records eked out with a number of groundless text-book traditions. No excuse seems necessary, therefore, for publishing this attempt to sift the facts and ascertain the truth.

Through the kindness of my friend Dr C. M. Wenyon (now Lieut.-Col., R.A.M.C.), I was able to see the coccidia which he described from man in 1915 . Since then I have seen and studied one of his forms anew, and have found another and apparently unrecorded species which will be described later in the present memoir. As there has hitherto been much doubt regarding the relation of the human coccidia to those occurring in certain animals, I have also re-examined the species in question in order to supplement my knowledge of these organisms and to corroborate and check the opinions which I had reached, concerning the parasites of man, from my study of the literature and of the parasites themselves.

My researches on the coccidia - begun in 1906, and continued intermittently ever since-have given me a fairly extensive acquaintance with the group as a whole, and with the works, both ancient and modern, dealing with them. Without this knowledge I could not have attempted the present revision, nor should I have been able to express an opinion, on certain matters, with a degree of confidence such as the reader may sometimes observe in the following pages. I have dealt with much of the previously recorded work on the coccidia of man in a very critical spirit, because I wish to show how little is really and rightly known about this interesting group of forms, and how large a field there is, in consequence, for the activities of future investigators. If the present work succeeds in unravelling some of the old tangles, and provides a clue for other workers, who have the opportunity, to follow up, it will have served its purpose. None can be more conscious than I am myself of its numerous shortcomings.

To obtain the original works describing the coccidia of man, and those related to them, I have had to ransack many of the large libraries in London and elsewhere, and $I$ take this opportunity of recording my indebtedness to the librarians who have everywhere aided me most willingly. It would be tedious to enumerate all the libraries ${ }^{1}$ which I have made use of, and to thank

1 For the benefit of others I should like to mention, however, that the works of Rivoltawhich are of considerable systematic importance-have proved most troublesome to obtain; but I finally succeeded in discovering copies of them in the library of the Royal College of Veterinary Surgeons, and should like to express my thanks once more to the Secretary, Mr F. Bullock, who recently unearthed them and enabled me to study them there. 
again individually all the friends who have, at one time and another, helped me to obtain works which are not readily accessible. I would ask them collectively, therefore, to accept again this expression of my gratitude. I am further beholden to several of my friends for information or assistance, which will be acknowledged in the proper place. I must, however, make special mention here of my indebtedness to Captain F. W. O'Connor, R.A.M.C., who-when he found that I was engaged upon the present work-most magnanimously placed at my disposal all his unpublished observations upon the Isospora of man. They were naturally of great interest to me, and I have availed myself of his generosity to the extent of incorporating some of his results, with due acknowledgments, in my account of $I$. hominis (Part II, sect. 1). I gladly offer him my thanks again here for his unselfish action.

I have only to add that I have completed the present work, and made most of the original observations recorded in it, whilst working with the aid of grants from the Medical Research Committee. Without this assistance, and the experience and knowledge gained whilst working on their behalf, the work itself could certainly never have been undertaken.

\section{PART I.}

\section{HISTORIC AND ANALYTIC.}

The history of our knowledge of the coccidia of man is difficult to write. It is complicated by the circumstance that our knowledge of the Coccidia, as a group, is comparatively recent ${ }^{1}$, whilst most of the original cases of human coccidiosis were recorded during the early period of ignorance and uncertainty, and usually by workers with very scanty knowledge of the organisms related to those which they described. The older accounts are thus frequently written in an archaic language which is not easily comprehended - or which is, at least, apt to be misunderstood-by a modern worker unversed in the history of this particular branch of protozoology. To add to the difficulties of exposition, the coccidia of man are related to, and have frequently been confounded with, those of other animals; and these latter coccidia are unfortunately among the species which have changed their names periodically. We have thus to cope not only with discrepancies and difficulties in matters of fact, as recorded by different observers, but also with a confusing change and interchange of names which has thrown the nomenclature of the entire group of species into a state of chaos.

In considering the cases and findings already recorded, I have thought it best to divide my analysis into two distinct parts-one dealing with the work done prior to the year 1915, and comprising therefore all the older observations; the second dealing with the observations recorded from 1915 to the present day. I adopt this procedure because the year 1915, in which the observations

1 The life-history of the coccidia, it may be recalled, was not properly understood until the publication of the celebrated researches of Schaudinn and Siedlecki in 1897. 
of Wenyon were published, marks a turning point in our knowledge of the coccidia of man. After this preliminary analytic section, I will attempt to deal with the resultant facts in a synthetic manner, and to show as clearly as possible the present state of our knowledge of the whole subject.

\section{A. The Human Cases of Coccidiosis described prior to the YEAR 1915.}

In dealing with the records of coccidial infection of human beings, I shall first consider the observations of each worker separately, and as far as possible in historic sequence. I may remind the reader, however, before doing so, that the name Coccidium - now, as a generic name, generally replaced by Eimeria -was introduced by Leuckart in 1879, and that previous to that date the organisms now called coccidia were generally known as "psorosperms"; whilst the condition of being infected with them--now called coccidiosis-was described as "psorospermosis"." The name "psorosperm" was introduced by Johannes Müller, in 1841, to denote the spores of those remarkable organisms now called by Bütschli's name Myxosporidia; and the coccidia were generally distinguished from these as "oviform" or "egg-like" psorosperms, on account of their resemblance to the ova of many metazoa. It should be remembered, however, that "psorosperm" was a name often loosely applied not only to the coccidia but also to the spores of gregarines, and to other "Sporozoa" (Sarcosporidia, etc.), and for a long time it had no very precise meaning.

Gubler's case. The first recorded case of coccidiosis in a human being is probably that described by Gubler $(1858,1858 a)^{2}$. His patient was a quarryman aged 45 who died, apparently from peritonitis, in a Paris hospital. He suffered from digestive troubles, anaemia, and other disorders, and his liver was much enlarged. At the post mortem examination it was found to contain many tumours of cancerous appearance--some of them very large-in which were numerous "ovoid cells," which Gubler was disposed to regard as "the eggs of helminths." They are said to have been "at least four times larger" than the largest cells of the surrounding tissues, but no other indication of their size is given. As regards their structure, he says that "some of them were very regularly ovoid with a perfectly distinct double contour, and completely filled with a finely granular contents, the others more or less flattened, shrivelled, and apparently empty." The two ends of the "cells" were unlike - "one is rather blunter, the other shows a slight constriction... and ends with a small and somewhat flattened or even very slightly depressed surface, as though an operculum or micropyle were present." The protoplasm forming

1 This term has survived until comparatively recently in medical literature, though it has long since vanished from zoology. Cf. Allbutt and Rolleston's System of Medicine, Vol. II, 1907, where the coccidia of man are reviewed under the heading "Psorospermosis."

2 See also Davaine (1860), p. 263, who quotes Gubler's papers in extenso. So far as I have collated them, Gubler's two papers are identical in contents. 
the contents was sometimes contracted from the wall. Gubler regarded these structures as probably the "eggs of a distoma," but emphasized their resemblance to the "eggs" found in the liver of the rabbit. His descriptions are unaccompanied by figures ${ }^{1}$, but they appear to relate to bodies which certainly resembled the oocysts of Eimeria stiedae--the coccidian parasite of the rabbit's liver.

Gubler states that his observations were confirmed by Davaine, to whom he showed his "ovoid cells." Davaine (1860), however, while agreeing that the "oviform bodies" were "like the smaller variety ${ }^{2}$ in the liver of the rabbit," adds that, at the time when he saw them, they were "unfortunately in an advanced state of decomposition" (p. 263). Leuckart (1863), who did not himself see Gubler's "cells," says that the case should probably be regarded as one of "so-called psorosperm formation"; and later (Leuckart, 1879) he definitely pronounced the bodies to be "Coccidia." He considered them to be the same as those which he himself recorded from other cases (vide infra). Leuckart $(1879$, p. 279$)$ claims that he was the first to point out "the true nature" of Gubler's oviform bodies in 1863. It is true that he suggested (1863, p. 49 , footnote) that they might be "psorosperms," and added later (Appendix, p. 740) that they certainly were "psorosperms." Nevertheless, his claim to have identified Gubler's bodies as coccidia in 1863 is not easily reconciled with his own statements at that date: for not only does he say elsewhere in this same work that "in man psorosperms have not been found with certainty" (p. 142), but he also says that, for his part, he is "most inclined to consider these [i.e. 'psorosperms'] as pathological tissue-elements" (p. 49, footnote). No doubt he forgot these statements afterwards (1879). Virchow (1860), who considered "psorosperms" to be "entozoic" in character, had previously expressed the opinion that Gubler's bodies were neither worm eggs nor psorosperms, but vacuolated cells such as he had found in cancerous growths.

It seems clear, therefore, that neither Gubler nor his contemporaries were able to identify with certainty the bodies which he had discovered. This can scarcely be wondered at, when it is remembered that very little indeed was known about the coccidia at that date, and the most divergent views were held about their nature. Later writers, however, have been unanimous in regarding Gubler's case as one of hepatic coccidiosis, and there is much to be said for this view.

Kjellberg's case. The first case of intestinal coccidiosis in man appears to have been discovered by a Dr Kjellberg, of Stockholm, in the Pathological

1 Leuckart, in referring to Gubler's paper (1858), ends the reference with "mit Abbild." See Leuckart (1879), p. 279, footnote. There are no figures, however, and no references to any, in the copies of the Mém. Soc. Biol. or Gaz. Méd. Paris which I have consulted.

2 Davaine (1860) considered that there were "two kinds of oviform corpuscle" in the liver of the rabbit. From his descriptions it appears that the "smaller variety" was merely a selection of the smaller-sized oocysts of Eimeria stiedae before their contents had undergone contraction and segmentation. 
Institute at Berlin. The findings are recorded by Virchow (1860), who says that the parasites were found in the villi of the small intestine. Virchow adds that the "psorosperms" in this case "agree completely with those which I have seen in the dog." He describes the latter as " paired psorosperms" "relatively small bodies, regularly arranged together in two's, provided with a strong double-contoured membrane." There can thus be little doubt that he had in mind the canine form of the coccidian parasite now generally known as Isospora bigemina. This supposition is strengthened by the fact that he further compares Kjellberg's "psorosperms" with similar bodies which he himself had found in the kidney of a bat, and of which he gives some figures. So far as I am aware, this parasite has never been studied or described since; but from Virchow's account, it seems probable that it was also a species of Isospora (=Diplospora).

It therefore seems probable that $\mathrm{Kjellberg} \mathrm{discovered,} \mathrm{in} \mathrm{the} \mathrm{small} \mathrm{intestine}$ of man, a coccidian belonging to the genus Isospora, and closely resembling that of the $\operatorname{dog}$ (I. bigemina).

Virchow's case. Virchow (1860) further described and figured some bodies which he had himself discovered in the liver of a woman. They were somewhat large oval structures - some 75 microns in length 1 — with a thick shell surrounded by a gelatinous envelope, and with protoplasmic contents strongly suggesting helminth ova undergoing segmentation. Virchow regardéd these bodies as "worm eggs," and suggested that they probably belonged to a pentastomid. He failed, however, to find any "worms" associated with them. Some later writers have pronounced Virchow's case to have been one of hepatic coccidiosis, believing the "eggs" to have been the oocysts of a coccidium. Railliet (1895), for example, says that Virchow's parasite was "quite clearly a coccidian" (p. 133); but I cannot find the slightest justification for such a statement. In my opinion the bodies found by Virchow were almost certainly not the oocysts of a coccidium, but were probably, as he believed, ova of a metazoan parasite. In any case, they seem to have been very different from the hepatic coccidia of Gubler, and cannot possibly have been the oocysts of Eimeria stiedae.

Eimer's cases. In his well-known work on coccidia, Eimer (1870) records the finding of "psorosperms" in two human bodies in the Pathological Institute in Berlin. The histories of the cases were almost unknown. "The alimentary canal was filled, and its epithelium completely infiltrated" with the parasites: Beyond noting that "the form of the 'psorosperms' was here the same as in the aforesaid animals" he gives no description of them. "The aforesaid animals," it may be noted, included mice and others, and the coccidia infesting them probably belonged to several different genera. In my opinion it is now quite impossible to identify Eimer's "psorosperms" with certainty.

1 Virchow (1860) states that the length of the structures was 0.003 of a Paris inch. Blanchard (1889) and nearly all subsequent commentators give their length as $56 \mu$. 
They were probably coccidia of some sort, though even this is open to question. Even their habitat cannot be exactly determined-in fact we know only that they occurred in some part of the gut ("Darmkanal"), and not in the liver.

Leuckart's cases. In his books on the animal parasites of man, Leuckart cites several cases of coccidiosis. These have long been copied from book to book, together with Leuckart's opinions on them, without criticism. As they have thus come to occupy an important place in the literature of this subject, I shall examine them in some detail.

It should be noted first that none of the cases cited by Leuckart was his own. They were all discovered and communicated to him by others. As noted above, he makes reference in the first edition of his book (Leuckart, 1863) to the "psorosperms" previously found in the human liver by Gubler. In the Appendix to this work (p. 740) he was able to add a second, and apparently similar case, communicated to him- by a Dr Dressler of Prague. The case is mentioned by him again later (Leuckart, 1879, p. 281), and accompanied on both occasions by a woodcut from the sketches which Dressler had made of his findings. So far as I can determine, Leuckart himself never saw the actual specimens: he saw only the drawings which he reproduces. From the description and figures the following facts can be obtained. Dressler found three small nodules-varying in size from that of a millet seed to that of a pea-in the margin of the liver of a human cadaver. Nothing further is recorded about the case itself. Inside the nodules was a whitish pulp, containing oval bodies which were--to judge from the drawings - the unsegmented oocysts of a coccidian. Their length appears to have been about 18-20 $\mu$; otherwise they are not unlike the oocysts of Eimeria stiedae from the fresh liver of a rabbit. If we accept the statement that they were "psorosperms" or "coccidia," there is, nevertheless, no information in the descriptions which will enable us to determine the genus, let alone the species, to which they actually belonged.

The second case cited by Leuckart $(1879$, p. 281) was discovered by one Prof. Sattler of Vienna. A preparation, which he had made for the purposes of a course in pathological anatomy, was found to contain "a dilated bile-duct with greatly proliferated epithelium and coccidia" (Leuckart). Nothing appears to be known about the case from which the material was obtained. It is implied, though not definitely stated, that it was human. Sattler did not send the preparation to Leuckart, but to a Prof. Perls of Giessen, who sent it on to him, together with a drawing which is not reproduced. Leuckart says he was able to convince himself "of the true nature" of the coccidia by his examination of the specimen: but he notes that "the contents of the coccidia" had been "completely cleared" by mounting in glycerine, so that "the bodies in question could easily have been taken for distomum eggs (D. lanceolatum $\left.{ }^{1}\right) . "$

1 It is perhaps worth noting here that the eggs of this trematode (now known as Dicrocoelium lanceatum) are $38 \mu$ to $45 \mu$ in length or rather more than twice the length--that is, if his own figures are correct-of the "coccidia" which Leuckart says could be mistaken for them. 
It must be confessed that the description of this case is far from satisfactory, and the identification of the "coccidia" now quite impossible.

Leuckart (1879, p. 282) gives yet a third case, "in which likewise our coccidia were demonstrable," which was also sent to him by Perls. It consisted of a preparation out of a collection made by von Sömmerring and later incorporated in that of the Pathological Institute at Giessen. No description is given either of the case or of the parasites, but Leuckart says that the specimen was labelled "an Distomis orta." He believed this to be a corrupt reading of "an Distomatis ova?." And it may be noted that at that date it was quite usual to regard the oocysts of coccidia as eggs of trematodes or other worms. Nevertheless, I cannot regard this case as anything but highly doubtful. Even if it be granted that the preparation contained coccidia, there is no proof that they were of human provenance. The origin of the preparation is unknown, its authenticity unvouched for, its label admittedly wrong. And it is far from improbable that the coccidia--if such they were--which it contained were those of the rabbit. For it is by no means unlikely that von Sömmerring, when engaged in collecting materials for a study of ulceration of the bile ducts, should have included in his collection specimens illustrating a condition so common in the rabbit and already well known at that date.

The three cases just described constitute the whole of Leuckart's contribution to the facts concerning human coccidiosis. Dressler's case, which he never saw, is, perhaps, the best attested. There is a very brief account of it, it was known to be a human case, and we have Dressler's own drawings of his findings from which to form an estimate of his parasites. Sattler's case, of which Leuckart saw a bad preparation and a drawing, and of which he learnt otherwise at third hand, is far more questionable. One may well hesitate to draw any definite conclusions from it. Finally, the case of Perls (von Sömmerring's preparation) has so little to support it, that, by itself, it is almost without value. If hepatic coccidiosis were a common condition in man, these last two cases might, perhaps, be less open to question. But when they constitute more than a third of the known, or alleged, cases on record, they require something more than Leuckart's loose statements for their substantiation.

Leuckart's opinions concerning the cases which he recorded are well known, and will be considered again later. It will suffice to note here that he regarded, without any apparent justification, all the hepatic coccidia of man as identical with those which occur in the liver of the rabbit.

Although it will be evident from what has just been said, I would here emphasize the fact that the original cases of human coccidiosis recorded by Leuckart are only three in number. Later authors have, apparently, been misled into supposing that there were four or even five $\mathbf{1}^{\mathbf{1}}$. I would also note

1 The five cases sometimes given are those of (1) Dressler, (2) Perls, (3) Sattler, (4) von Sömmerring, (5) Leuckart. From the foregoing account it will be clear, $I$ think, how this misconception has arisen. 
that all were cases of hepatic infection-Leuckart himself having never studied or described any cases of intestinal coccidiosis in man.

Rivolta's cases. It is generally supposed that cases of human coccidiosis were studied and described by Rivolta, and his name is almost invariably cited as one of the authorities on the subject. The facts, however, appear to be as follows.

Rivolta (1873) mentions somewhat casually (p. 565) that he found some "corpuscles in the faeces" of "a man afflicted with intermittent fever"; and he gives (Plate X, fig. 317) some rude sketches of them, described (on p. 580) as "corpuscles in the faeces of a man suffering from tertian fever." The bodies in question were "large white cells, with somewhat indistinct contour and homogeneous whitish contents; they had an oval shape, some of them also being round or piriform" (p. 565). To judge from the figures, they were about $8 \mu$ in diameter: and although it is impossible to identify them. I may hazard the guess that they were the cysts of Entamoeba nana, which are far from uncommon in human faeces. Rivolta himself does not even suggest that his "corpuscles" were coccidia. So far as I can discover, he nowhere refers to them again; and in none other of his publications is there any mention of his having found coccidia - - or any other protozoa - in the faeces or tissues of man. Grassi (1879), however, cites the above passage from Rivolta, and compares his findings with the supposed "Psorosperms" which he himself found in the faeces of human beings. But as we shall see (vide infra), Grassi's own "coccidia" were not coccidia at all, but the cysts of other protozoa.

In a later work, Rivolta (1878) proposes the name "Cytospermium hominis" for the "psorosperms" found in man by Eimer (1870). The name is proposed explicitly for these forms, and not for any organisms which he had himself studied or described. Its application turns, therefore, upon the identification of Eimer's parasites.

From a careful study of all the available sources of information, I have no longer any doubt that Rivolta neither discovered nor described any coccidial parasites of man, and that the cases attributed to him are due to a mistake which has become traditional. Its origin, I believe, is to be traced to Blanchard, who has been copied - without verification, and often with inaccuracy - by all later writers on human coccidiosis. But I shall return to this point later.

Grassi's cases. Grassi, like Rivolta, is almost invariably cited as a discoverer of coccidia in man; and, as I shall attempt to prove, with equally little justification.

As noted above, Grassi (1879) described some "corpuscles" which he had found in human faeces and which he regarded at the time as coccidia. They were found in two cases-a boy and a young man-in one of whom the infection was followed for some two-and-a-half months. From the brief description and figures in the original paper it is clear that the "corpuscles" were not coccidia at all, but probably the cysts of Giardia (=Lamblia) in- 
testinalis and Entamoeba coli. This supposition is confirmed by Grassi's later writings. He there says definitely (Grassi, 1882, 1883) that the "special corpuscles" which he had previously described in human faeces were not coccidia. The larger forms were "resting amoebae"; of the identity of the smaller he is still in doubt. From his figures and description, however, it is certain that these were, for the most part, cysts of Lamblia, which Grassi and Schewiakoff (1888) identified and described at a later date.

It appears perfectly clear, therefore, that the "coccidia" discovered in human faeces by Grassi have no foundation on fact. Grassi himself, indeed, has denied that he ever found coccidia in man. He says (cf. Grassi, 1883, p. 442) that some of the "corpuscles" which he had earlier described were only "perhaps related to the coccidia": and he is indignant with Bütschli (1881) for having said that "their coccidial nature is still pretty doubtful." Bütschli, he says, had credited him with believing that they were coccidia in order to have the pleasure of making this retort. Nevertheless, there is good evidence that Grassi originally did believe that the "corpuscles" in question were coccidia ${ }^{1}$, although he satisfied himself later that they were not. The matter is clinched by his own statement some years later that he "has never found intestinal coccidia in man" (Grassi, 1888, p. 5).

It is therefore certain, I think, both from his own testimony and from a careful consideration of his publications, that no real cases of human coccidiosis were ever discovered or described by Grassi.

Kunstler and Pitres's case. The case described by Kunstler and Pitres $(1884,1884 a)$ differs from all the others which we have to consider, in that the parasites were found, not in the liver, gut, or faeces, but in the pleural cavity. The patient was a man of 27 serving on board a ship plying between Bordeaux and Senegal. He entered hospital at the former place, suffering from pleurisy. About 2 litres of pus were evacuated from the pleural cavity by tapping. Examined microscopically, it was found to contain "a large number of ovoid or fusiform corpuscles,--homogeneous, of hyaline appearance, and swimming freely in the liquid of the preparation or enclosed, to the number of ten to twenty or more, in clear and relatively voluminous vesicles. The isolated corpuscles measure usually from 18 to $20 \mu$ in length; exceptionally, smaller (8 to $10 \mu)$ or much larger ones $(60$ to $100 \mu)$ are found." The "corpuscles" displayed a "finely striated envelope," and a central body believed to be a nucleus. In the opinion of their discoverers they were probably "the falciform bodies of psorosperms"- that is, the merozoites or sporozoites of a sporozoon - "living parasitically in the pleural cavity."

1 This is not only implied by the title of his paper (Grassi, 1879), but is distinctly stated in it. After discussing the nature of his "corpuscles," he concludes by saying that he is "forced to the conviction that they are psorosperms." "Ed io li giudico psorospermi dell' uomo.... I psorospermi da me descritti entrano nella sottofamiglia dei psorospermi oviformi-sferici" (p. 635). Allowing for the language of the period, he could hardly have expressed the opinion that they were coccidia with greater clearness. 
The account given by Kunstler and Pitres, taken in conjunction with their illustrations ${ }^{1}$, is to me extremely puzzling. I am unable to form any exact idea of the true systematic position of their parasite. I am by no means convinced that it was even a sporozoon of any sort-still less that it was a coccidian belonging to a familiar genus. This, however, was the view taken by Blanchard, who, in 18952 , proposed the name "Eimeria hominis" for it. It is certain, at all events, that it cannot be placed in the genus Eimeria (Aimé Schneider, 1875) as now understood; and Blanchard's proposal was undoubtedly due to the imperfect knowledge of the coccidia prevailing at the time when he wrote. I conclude that "Eimeria" hominis Blanchard is certainly not an Eimeria, and that future work alone can show what the organism in question really was.

Podwyssozki's cases. Podwyssozki (1889) stated that he had observed four human cases of infection of the liver with "coccidia." The "parasites" live in the cells and their nuclei; they are difficult to find and recognize; and they are probably a cause of cirrhosis. "They attain the size of a considerable oval body, with a thick membrane, and containing one or several spores." The name "Karyophagus hominis" was first proposed for them (Podwyssozki, 1889); but later their discoverer stated that they "belong to the family of the Coccidia and probably to the Coccidium oviforme" (Podwyssozki, 1892). It is difficult, however, to recognize any resemblance to the coccidia of the rabbit's liver either in the descriptions or in the figures of these and similar structures published by Podwyssozki and Sawtschenko (1892).

I shall not consider these "parasites" further here. There is, I think, no longer any doubt that Podwyssozki's "coccidia"-like those described in cancerous growths by many others subsequently-were not coccidia at all, but cellular elements and cell-inclusions of various sorts which were mistaken for parasites.

Railliet and Lucet's cases. After redescribing the dog's coccidial parasite, originally called "Cytospermium villorum intestinalium canis" by Rivolta, Railliet and Lucet (1890) briefly record that they had discovered a similar organism in human beings. They had two cases-a woman and her child, who had both long suffered from chronic diarrhoea. The parasites were found in the faeces. They had a "regular ovoid form,"..."a certain number containing granular protoplasm with numerous refractile globules," whilst "others contained a large granular mass without these globules." Their mean length was $15 \mu$, their breadth $10 \mu$. The authors did not figure these

1 Illustrations accompany their second paper (Kunstler and Pitres, $1884 a$ ) only. The quotations given above are from their first paper (1884).

2 I give this date on the authority of Blanchard himself (see Blanchard $(1896,1900)$ in bibliography). 'The first use of the name which I have been able to find is in his article in Bouchard's Traité, where he calls the organism "Eimeria hominis R. Blanchard, 1895," but gives no reference to the work of 1895 in which he proposed the name. I have not been able to find it. The second volume of Bouchard's work-in which Blanchard's account appears-is dated 1896. 
bodies; nor did they, at this time, propose any name for them. They appear, however, to have regarded them as closely similar to the coccidia found in the intestinal villi of carnivores (dog, cat, polecat, etc.); that is to say, to the organism now generally known as Isospora bigemina. But they add that "the contents" of their human parasites "was sufficiently unlike" these.

A little later, Railliet and Lucet (1891) return to the coccidia of the Carnivora and accept the name then just bestowed upon them by Stiles (1891),namely, Coccidium bigeminum. But they propose to subdivide the species into varieties corresponding to the different hosts in which the parasites had been found. The form in the dog they name $C$. bigeminum var. canis; that in the cat, var. cat $i$; that in the polecat, var. putorii; and they add that there is perhaps a fourth, var. hominis, in man. Strangely enough, however, they make no mention of their own discovery in this connexion, but state that hominis "corresponds to the form observed by Kjellberg."

Railliet (1895), however, a few years afterwards, states that Kjellberg's parasite was probably Coccidium bigeminum (p. 146); and on another page (p. 140) he says that the forms found in human faeces by Railliet and Lucet probably belonged also to the same species.

It would appear, therefore, that Railliet and Lucet discovered two human cases of infection with an organism which they believed to be similar to Isospora bigemina of divers carnivores; that they identified it with the parasite previously found by Kjellberg; and that they proposed tentatively to name it Coccidium bigeminum var. hominis. The identity of Railliet and Lucet's parasites is, nevertheless, not beyond dispute. It is, in fact, impossible to recognize them as coccidia from their description alone. We have only the authors' opinions unsupported by any cogent facts; and the dimensions of their "coccidia" seem, at first sight, to contradict their hypothesis that the human parasites which they discovered could be a variety of Isospora bigemina. It is clear from their accounts, however, that-like other workers at this time--they did not understand the morphology of the "bigeminate" coccidia of carnivores. The two spores within the oocyst were regarded as two separate "coccidia"; and the measurements which they record relate, accordingly, in every case to the sporocysts-not the oocysts-of the parasites". It is therefore possible that their human parasites, in spite of their apparently very small size, may really have been closely similar to Isospora bigemina.

Silcock's case. The only case of human hepatic coccidiosis described in England has been recorded by Silcock (1890). The patient was a woman aged 50 who died at St Mary's Hospital, London, in 1889. The chief symptoms noted before death were enlargement of the liver and spleen, fever, and slight diarrhoea. At the autopsy the liver was found to be "much enlarged," and to contain "a number of caseous foci arranged in groups," each of them surrounded by "a well-marked red ring of inflammatory congestion." The spleen

\footnotetext{
1 See Railliet and Lucet $(1890,1891)$ and Railliet (1895).
} 
showed "similar caseous foci." In the ileum were "six papule-like elevations with circumferential inflammatory zone," and in the large intestine "deeply congested patches of mucous membrane from 1 to 3 inches square." The caseous nodules-superficially resembling tuberculous lesions - "consisted largely of agglomerations of small, oval, egg-like bodies, with granular contents and well-marked capsule." The bodies were found "in the liver cells and in the bile ducts," and Silcock states that they were "identical in every respect with the coccidia described" by Leuckart "in cases of parasiticism (sic) in man and rabbits by the Coccidium oviforme." "On cultivating the coccidia... by keeping small affected portions of the organs in water... psorosperms were freely developed." He remarks that he has nothing else to add to Leuckart's description of the organisms, and gives no figures. It may be noted that Silcock's coccidia were apparently present in the liver and in the spleen - a remarkable situation. But although lesions are also mentioned in the gut, it is not explicitly stated whether similar parasites were found in them or not.

From Silcock's imperfect account it is now impossible to ascertain what he really saw. He seems, most unfortunately, to have thought that Leuckart had already fully investigated the hepatic coccidia of man-as was by no means the case. It seems clear that Silcock's coccidia resembled Eimeria stiedae, since he specifically mentions "Coccidium oviforme." But he gives no indication of their size, and does not appear to have noticed that the oocysts of the human coccidium figured in Leuckart are only about half the size of those from the rabbit. Moreover, Silcock himself was-all unawares-actually the first to study the development of the spores within the oocyst of the human parasite $^{1}$; and it is most regrettable that he makes no mention of their number, form, or contents, since it is upon these that the identity of the parasite turns. Of the human parasite Leuckart saw nothing but the unsegmented oocysts, or drawings of them. His figures of "Coccidium oviforme" relate exclusively to the parasite of the rabbit; and his assumption that the two forms develop in the same manner, and are, $\because$ in fact, the same species, is quite gratuitous. Silcock gives no reference to the work of Ieuckart which he consulted, and he obviously cannot have studied his writings with any care. Had he done so, he might have been able to add much to our knowledge: but as it is, we can only guess what he really found.

Giles's cases ${ }^{2}$. In a work dealing with kala-azar and ankylostomiasis in Assam, Giles (1890) records the finding of numerous "coccidial" infections among the natives. Examination of his figures and descriptions leaves no doubt in my mind that his "coccidia" were really vegetable cell débris in the faeces of his patients. They were often present in "astonishing" numbers.

1 Or, as he termed it, the development of "psorosperms" in the "coccidia" on "cultivation."

${ }^{2}$ I have here to thank my friends Dr A. C. Stevenson and Dr G. C. Low-the former for directing my attention to Giles's observations, the lațter for obtaining his publication for me.

Parasitology $\mathbf{x T}$ 
"They vary a great deal in size," but are "generally very much larger than the ova" of Ankylostoma..."averaging about $\frac{1}{50}$ inch [about $170 \mu$ ] in diameter." "They are by no means uniform in shape. . differing in fact from ova much in the same way that potatoes do from eggs." And so forth.

It will be sufficient for our present purpose to note that Giles's bodies, whatever else they may have been, were certainly not coccidia.

Jürgens's case. At the post mortem examination of a workman, aged 66, Jürgens (1895) discovered some peculiar "bodies" in growths in the dura mater of the brain and spinal cord. One of the rabbits which he inoculated from these subsequently developed numerous tumours-in the orbit, and various other places-which were believed to contain similar bodies. For reasons which are not apparent, the author regarded the bodies as a "species of coccidium"; but he added that "as regards size, shape, and sporulation it differs essentially from Coccidium oviforme, or perforans." Most people, on reading his account, will, I think, be disposed to go further than this; and they will probably conclude, as I do, that his "bodies" differed materially from all known coccidia, and consequently that his case was not one of coccidiosis.

Quincke's cuses. Quincke (1899) has described bodies which he found in the faeces of two human beings, and which he regarded as coccidia. His first case (Case I), a man of 40 , suffering from diarrhoea, was passing numerous " hyaline, oval structures, $12 \mu$ long, $8 \mu$ broad." These Quincke considered to be coccidia similar to those described by "Baillet" and Lucet, Grassi, and Rivolta. (What these authors actually described we have already noted.) From the description and figures, there can be very little doubt that Quincke's "coccidia" really were identical with those described by Grassi; that is, they were the cysts of Lamblia intestinalis, and not coccidia at all.

Quincke's second case (Case III) passed different bodies, which it is suggested were possibly coccidia. They were undoubtedly in reality Blastocystis hominis. The figures unmistakably depict this common vegetable organism of the human bowel.

It is thus clear that neither of the cases described by Quincke was one of coccidial infection.

Thomas's case. In the brain of a woman, aged 40, who died of pneumonia, Thomas (1899) found a bony tumour the size of a small pea. Microscopic examination of this led him to conclude that it had been caused by the presence of coccidia-which he identified as "Coccidia oviformia"--in the brain. The occurrence of the hepatic coccidia of the rabbit in the human brain, however, would be so remarkable a phenomenon, that it would require much stronger evidence for its verification than the author appears to have been able to adduce'. It seems, indeed, more than probable that Thomas was mistaken in his conclusions, and that the structures which he observed were not coccidia.

I I have not been able to consult the full account of this case, which was to have been published -according to the abstract (by Nuttall) in the Centralbl. f. Bakt.-in the Boston Hospital Reports. 
Grunow's case. Grunow (1901) has described at length a case of enteritis believed to be due to protozoa-probably coccidia. The patient, a workman aged 61, had suffered for some time from diarrhoea. In his stools Grunow found round "bodies" about $6 \mu$ to $8 \mu$ in diameter, but sometimes larger. These, for reasons which are not apparent, were regarded as probably coccidia. From the description it is not possible to identify them. At the post mortem examination the small intestine was found to be ulcerated, and in sections of it the author succeeded in finding in the villi some other "bodies" which he was likewise disposed to regard as coccidia. The size of these is given as "4.9-7.3 broad, 7·3-9.8 long" (presumably microns). Although there was nothing to prove that the bodies in the faeces were in any way connected with those in the villi, the author united them by the following curious argument: "The parasites found in the faeces and in the mucous membrane are indeed different in form, nevertheless identical in their parasitic nature." $\mathrm{He}$ concludes by deciding that they are all probably coccidia, and if $s o$, then Coccidium bigeminum. Comment is needless.

It is unnecessary to discuss this case in greater detail. There is not even the slenderest evidence that the various "bodies" in question were even protozoa; and probably nobody acquainted with these organisms will, after reading Grunow's account, be inclined to agree with him that his case was one of coccidiosis.

To the foregoing cases I will add, for the sake of completeness, a few notes on certain others which are now generally recognized as not coccidial, though at one time held to be such. The most important of these are the cases of infection with the two organisms now known as Coccidioides and Rhinosporidium: the rest are the very numerous cases in which "pseudo-coccidia" have been described and causally connected with divers diseases.

Coccidioides. This organism is now known to be a fungus. It invades the skin, central nervous system, and other organs, giving rise to the disease generally known as "coccidioidal granuloma." Some fifty cases are known, mostly from California. The parasite was discovered in S. America by Posadas, and considered by him and Wernicke (1892) to be a "coccidium." Rixford and Gilchrist (1896), who subsequently studied the parasite and the disease in detail, regarded the organism as a "protozoon," of doubtful systematic position, and introduced the name Coccidioides immitis ${ }^{1}$ for it-a name suggested by Stiles. It has since been cultivated by Wolbach (1904) and others, and appears to belong to the Oomycetes².

1 Hartmann (1912), in ignorance of the fact that the organism was already well known and named, has more recently proposed the name "Blastosporidium schooi" for it, believing it to be a "Haplosporidian."

2 For further information and literature concerning this parasite, see-in addition to the authors cited above-- Evans (1909) and Dickson (1915). 
Rhinosporidium $^{1}$. This curious organism, which gives rise to polypoid growths in the nose, appears to have been discovered by Malbran in S. America in 1892. Another case was found there by Seeber in 1896, and first described by him in 1900. O'Kinealy independently discovered the organism in Calcutta in 1894, but did not describe it until 1903. Since then other cases have been studied, mostly from India. Wernicke regarded the parasite as a coccidian, and in 1900 named it Coccidium seeberi. Minchin and Fantham (1905), in ignorance of Seeber's work, restudied the organisms from 0'Kinealy's case and named them Rhinosporidium kinealyi. They regarded them as "Haplosporidia." Although the systematic position of Rhinosporidium is still very problematic, it may be stated with some confidence that it is almost certainly not a coccidium ${ }^{2}$. I may add that to refer any organism to the group Haplosporidia practically amounts, at the present moment, to a confession of ignorance of its true status.

Pseudo-coccidia. In addition to the highly questionable "organisms" which we have already had occasion to notice, "pseudo-coccidia"-bodies of various sorts mistaken for coccidia, "psorosperms," or related protozoa--have been described from almost every organ and part of the human body. Many of these have been found in malignant growths, and have excited a transient interest, and occasionally attained some celebrity, as "causes" of cancer. The cases of Podwyssozki, and his "Karyophagus hominis," have already been noticed. They will serve as an example of a class of cases and parasites too numerous to mention, and now of nothing but slight historic interest. The literature concerning these and similar "parasites" has been collected by Labbé (1899), whose work should be consulted by those interested in the subject.

Of other pseudo-coccidia it will suffice to mention a few of the best known. The oldest historically are those discovered by Lindemann $(1863,1865)$, who was one of the first to find "psorosperms" and "gregarines" in man. He recorded their presence in the heart, aortic valves, and kidney; and did not hesitate to identify the forms in the heart-muscle with the coccidia of the rabbit's liver-Eimeria stiedae-which he regarded as a Monocystis (cf. Lindemann (1865), p. 385). The value of his observations may be gauged from the fact that he also recorded the discovery of "gregarines" lying on the surface of human hairs-an observation at first accepted, but later justly censured by Leuckart (1879). Similar "coccidia" discovered in the kidneys and generative organs-especially of the female ${ }^{3}-$ by later investigators, deserve no further notice here.

1 For the facts, names, and dates given in this paragraph, see Seeber (1912) and Minchin and Fantham (1905). From Seeber's account it appears that the correct name of the organism is Rhinosporidium seeberi Wernicke, 1900.

2 On this point the views of Seeber and Minchin are in agreement. It is also the opinion which I have formed from the examination of some excellent preparations which my friend Dr J. H. Ashworth of Edinburgh has very kindly shown me.

${ }^{3}$ Cf. Pick (1895): "Our knowledge of the Sporozoa in gynaecology must, at the present time, be described as entirely negative." 
The "coccidia" found in the skin in Darier's disease ("psorospermosis follicularis vegetans"), in Paget's disease of the nipple, and in other affections, by Darier (1889) and others, are now generally recognized as modified epidermal cells (cf. Boeck (1891), etc.). The "coccidia" of molluscum contagiosum are probably of a similar nature ${ }^{1}$. These and similar diseases, once included among the "psorospermoses," have long ceased to be regarded as the results of coccidial infection.

In the preceding paragraphs $I$ have enumerated all the cases of human coccidiosis which, so far as I have been able to ascertain, had been put on record prior to the year 1915. I have omitted to consider in detail those cases only which, by general consent, have already been finally consigned to oblivion. It will be convenient at this point, before going further, to summarize briefly the main conclusions which may be drawn from a study of these cases. I will therefore do so: but $I$ would point out that these conclusions are drawn entirely from the facts recorded by the original describers of the various organisms concerned, and independently of the opinions of later commentators which will be considered in the next section.

(1) There is good evidence that at least nine of the authors who have described, or who are alleged to have described, coccidia from man, did not, in fact, do so. The organisms or structures which they found were certainly not coccidia. These authors are: Virchow (1860), Rivolta (1873, 1878), Grassi (1879), Podwyssozki (1889), Giles (1890), Jürgens (1895), Quincke (1899), Thomas (1899), Grunow (1901). The cases of human coccidiosis attributed to these workers should therefore be eliminated from the literature of the subject. To this index expurgatorius must also be added, of course, the names of all the describers of "pseudo-coccidia"; and for my own part, I am disposed to add also the names of Kunstler and Pitres (1884). Despite the authority of Blanchard, I cannot regard theirs as anything but a most questionable case of coccidiosis.

(2) This leaves us with only six works which record cases of infection with. organisms that can be regarded, with different degrees of certainty, as coccidia. The parasites were recorded from the liver, intestine, or faeces, as shown in the following synopsis:

In the liver, by

Gubler $\left(\begin{array}{llllllllll}1858) & \ldots & \ldots & \ldots & \ldots & \ldots & \ldots & \ldots & 1 \text { case }\end{array}\right.$

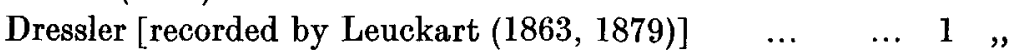

Sattler and Perls [recorded by Leuckart (1879)] $\ldots \begin{array}{llll}\ldots & \ldots & 1 & \text { ", }\end{array}$

Perls and v. Sömmerring (?) [recorded by Leuckart (1879)] 1 ",

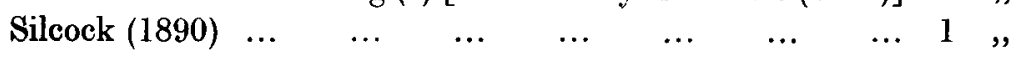

Carried forward $\overline{5 \text { cases }}$

${ }^{1}$ For the literature see Labbé (1899) and Lipschütz (1912). 
In the intestine, by

Kjellberg [recorded by Virchow (1860)] $\quad \ldots \quad \ldots \quad \quad \ldots \quad 1$ case

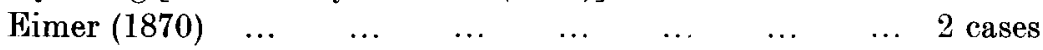

In the faeces, by

$\begin{array}{llllllll}\text { Railliet and Lucet }(1890) & \ldots & \ldots & \ldots & \ldots & \ldots & 2,\end{array}$

Total ... 10 cases

From this it may be concluded that human coccidiosis is not a common affection: especially when it is remembered that several of the above cases are, to say the least, by no means well authenticated ${ }^{1}$.

(3) As regards the parasites present in these cases, we find the information necessary for their identification either wholly lacking or exceedingly deficient. The coccidium inhabiting the liver appears to resemble Eimeria stiedae of the rabbit. There is no evidence, however, to prove that it is of this species; and there is some-namely, its size-to indicate that it is not. The coccidia found in the small intestine and in the faeces were, so far as there are any indications, of a species belonging to the genus Isospora, and resembling $I$. bigemina of cats and dogs. In short, there is evidence that man may harbour an Eimeria in his liver and an Isospora in his gut; but beyond this it would be hazardous to draw any inferences.

The foregoing conclusions may be fairly drawn, I think, from the cases analysed in the present section. At the same time, however, it must be pointed out that the cases considered-or at least some of them-appear less uncertain when viewed in the light of more recent work. The conclusions are here tentative, not final. They constitute merely a "vindemiatio prima," in the Baconian manner, before we proceed to study further instances. But it is well to state them clearly at this point, since they give us a basis of fact from which to judge the value of the opinions which have been expressed at various times by writers on human coccidiosis. The most important of these opinions I shall now chronicle as briefly as possible.

\section{B. Opinions concerning the Coccidial Parasites of Man, as expressed by the Chief Compilers and Commentators.}

Various writers have, on various occasions, held widely different views regarding the coccidia parasitic in man. These differences-so far as concerns us at present-are chiefly regarding (1) their systematic position; (2) their specific identity or diversity in respect to similar parasites occurring in other hosts; and, consequently, (3) their nomenclature. Even the most casual con-

1 For my own part, I am quite prepared to believe that the cases of Gubler, Dressler, Silcock, and $\mathrm{Kjellberg,} \mathrm{are} \mathrm{the} \mathrm{only} \mathrm{real} \mathrm{cases} \mathrm{of} \mathrm{human} \mathrm{coccidiosis} \mathrm{recorded.} \mathrm{But} \mathrm{such} \mathrm{a} \mathrm{view} \mathrm{is,} \mathrm{perhaps,}$ hypercritical. 
sultation of the literature on this subject will show that, in each of these respects, the view which any writer takes of the cocoidia of man depends very largely upon the opinions which he holds concerning the coccidia parasitic in rabbits, and those of dogs, cats, and other carnivores. Until recently there has been much uncertainty about these parasites; and it will greatly facilitate the comprehension of what I have to say in the ensuing paragraphs if the present state of our knowledge of them is made clear at the outset. I shall therefore devote a short space to the consideration of this subject before proceeding further.

The coccidia of the rabbit. As is generally known, the common rabbit, both wild and domesticated, usually harbours coccidia in its liver and small intestine. In the liver they infest the bile canal system, in the gut the epithelium of the mucous membrane; and in both situations they may give rise to pathological conditions of variable and sometimes fatal extent.

The coccidia of the liver were discovered by T. G. Hake, a London physician, in $1839^{1}$. He did not, however, understand their true nature; but regarded the lesions in the liver as "carcinoma," and the parasites as "a new form of the pus globule." As a result, however, of the labours of many later workers in several different countries - it will suffice to mention Remak, Kölliker, Stieda, Lieberkühn, Rivolta, Leuckart, and Balbiani-the parasites gradually came to be regarded in their proper light; so that by about 1880 they were generally recognized as protozoa belonging to the group of "oviform psorosperms" or Coccidia. Hake (1839) had already found oocysts in the contents of the duodenum, and later Klebs (1859) demonstrated the parasites within the epithelial cells of its mucous membrane. Since then there has been a prolonged controversy over these parasites, and even now it cannot be regarded as finally decided. The majority of modern workers follow Balbiani (1884) in regarding the coccidia found in the liver and the intestine as belonging to the same species- - the site in the host's tissues being their sole distinctive character. Others, adopting the standpoint of Leuckart (1879), regard the parasites of the intestine as specifically different from those in the liver, and advance various reasons in support of their belief. To my mind, the evidence at present available, both morphological and experimental ${ }^{2}$, is undoubtedly in favour of the

1 It may be noted that Hake's work contains the earliest account and figures of coccidia known. His drawings of the oocysts from the liver are admirable, and might serve as illustrations for a modern text-book.

2 The most important experimental evidence is that adduced by Railliet and Lucet (1891), Railliet (1895), and Lucet (1913). According to these workers the spores of the hepatic parasite, when ingested, produce a hepatic infection only: and similarly, those of the intestinal parasite produce an intestinal infection only. If the work of Lucet (1913) is sound, as there appears no reason to doubt, then it seems certain that his conclusions are correct-namely, that there are two distinct species in the rabbit. So far as my own observations enable me to judge, the morphological differences which he describes between these species actually exist, and at present I agree with his conclusions. Moreover, I can find no adequate arguments against his views in the work of Metzner (1903), Reich (1913), and others who hold an opposite opinion. 
latter view, which is that of some of the modern French writers. The former, which regards all the coccidia in the rabbit as belonging to one and the same species, is, however, that which has gained general currency in England and Germany.

The parasites of the liver and the gut both unquestionably belong to the genus Eimeria Aimé Schneider (1875). The correct name of the former is Eimeria stiedae Lindemann (1865) ${ }^{1}$, as was pointed out by Stiles (1902) and Lühe (1902); but it has been given several other names, of which the most important are Psorospermium cuniculi Rivolta (1878), and Coccidium oviforme Leuckart (1879). In all but the most modern works it appears under the names Coccidium cuniculi or C. oviforme.

The correct name of the coccidium of the rabbit's small intestine--assuming it to be a separate species-is Eimeria perforans Leuckart (1879). Those who regard the two forms as identical apply the name--whatever it may be--which they give to the hepatic form, to the intestinal form also, as the former was named before the latter. In many modern works, therefore, $E$. perforans appears as a synonym under $E$. stiedae. In the older writers it figures either independently as Coccidium perforans or as merely the intestinal form of "C. oviforme" or "C. cuniculi."

The intestinal coccidia of carnivores. The coccidia living in the intestinal villi of cats, dogs, and other carnivores, have also a somewhat chequered history. They were first seen in the dog by Finck (1854), who regarded them as metabolic products. Later workers-Virchow, Rivolta, Grassi, and others - recognized their parasitic character, and showed that they occur in the cat also $^{2}$. The chief features in their development have been made out by Grassi (1879 a), Railliet and Lucet $(1890,1891)$, Stiles (1891, 1892), and more recently by Swellengrebel (1914).

Rivolta called the parasites "oviform cells" or "Cytospermia" of the villi of the dog and cat ${ }^{3}$. They were subsequently named Coccidium Rivolta by Grassi (1879 a) and Coccidium bigeminum by Stiles (1891). They certainly do not belong to the genus Coccidium (Leuckart, 1879), which is a synonym of Eimeria (Aimé Schneider, 1875); and as they are characterized by possessing an oocyst containing two tetrazoic spores, they are now generally referred to Schneider's genus Isospora, and known as Isospora bigemina Stiles. It has not been determined with certainty whether the forms inhabiting different hosts belong really to the same or to different species. Most authors, however, follow Railliet and Lucet (1891) in considering the parasites occurring in different

\footnotetext{
1 Lindemann, it may be noted, called the organism Monocystis stiedae, and regarded it as a gregarine.

2 In both these hosts they are far from uncommon. Similar-possibly identical-forms have also been described in the pole-cat (Mustela putorius $\mathrm{L}_{\text {. }}$ ) and wild species of dog.

3 "Cellule oviformi dei villi del cane e del gatto" (Rivolta, 1874, 1877, 1877 a); "Cytospermium villorum intestinalium canis" (Rivolta, 1878).
} 
animals as varieties of the same species. In most works dealing with the Coccidia they are called collectively "Coccidium bigeminum 1 ."

Having said so much by way of introduction to this section, I will now pass on to its subject proper. I shall take the various authors in chronological order, as far as this is possible.

It has already been noted that Davaine (1860) saw Gubler's hepatic coccidia, and tentatively concluded that they were similar to those found in rabbits (i.e. to Eimerin stiedae). He called all these parasites "oviform bodies," and was inclined to regard them as the eggs of worms.

Of much greater importance historically are the opinions of Leuckart. As already noted, he first expressed the opinion that Gubler's case was "of doubtful nature." He included with it Virchow's and Kjellberg's cases (Leuckart, 1863, p. 49, footnote). Later, however, he decided that Gubler's case was one of "psorosperm" infection, and similar to Dressler's case and others which he had since had communicated to him (Leuckart, 1863; Appendix, p. 740). In his later work (Leuckart, 1879) he discusses all the parasites in greater detail. Translated into modern terms, his opinions were as follows: all the coccidia found in the human liver ${ }^{2}$ are of the same species as those found in a like situation in the rabbit. In other words, all are Eimeria stiedae (= Coccidium oniforme). All the coccidia found in the intestine of man $^{3}$, the rabbit, the cat, and the $\mathrm{dog}$, also belong to one species-namely, Eimeria perforans (= Coccidium perforans). This species therefore embraced Isospora bigemina in Leuckart's estimation.

Leuckart believed that human beings acquire their infections through contact with infected animals. He thus regarded the rabbit as a source of human contagion, for both the hepatic and intestinal coccidia; and for the latter, the

1 Although the organisms in question are now very generally known as Isospora bigemina Stiles, it seems probable that this is not their correct name. If we exclude Rivolta's lengthy Latin appellation (see preceding footnote) as not conforming with the rules of binominal nomenclature, the first name given to them seems to be "Coccidium Rivolta," bestowed by Grassi (1879 a). Why the specific name is written in the nominative instead of in the genitive case is not clear. At first sight it appears to be a lapsus calami; but Grassi repeats the name in the same form in at least two later papers (Grassi, 1882, 1883). It is clear, however, that he regarded the name as binominal, and intended it as a mark of honour to Rivolta. My own view is that this name should be amended by substituting the correct generic name, and putting "Rivolta" in the genitive case. The correct name would then be Isospora rivoltae Grassi (1879), which has priority over I. bigemina Stiles (1891). If anybody should object to this specific name on the grounds of Art. 14 of the International Rules, I would remark that the genitive termination -ae is good Latin for the name of a man ending in -a (e.g. Caligula, -ae; Cotta, -ae, etc.) in spite of the Rules; and further, that if Eimeria stiedae is an acceptable form of commemorating the Russian naturalist, then Isospora rivoltae should be equally acceptable for the Italian. Forms such as "rivoltai" appear to me to be unnecessary and objectionable solecisms. The difficulties connected with the generic name Isospora will be considered later. To avoid confusion, I shall, however, continue to call the coccidia of the cat and dog Isospora bigemina in the present paper.

${ }^{2}$ Leuckart (1879) knew of four cases-Gubler's, Dressler's, and the two cases sent by Peris (from Sattler and the von Sömmerring collection).

s The only human cases known to Leuckart were those of Kjellberg and Fimer. 
cat and dog also. If we seek his grounds for this belief, they are difficult to find. In fact his opinion appears to rest mainly upon a general belief that there are only a few species of coccidia. As evidence that the hepatic coccidia of man and rabbit are the same, he advances the argument that Gubler's case probably acquired his infection from a rabbit; for the singular reason that he lived in France, and France is well known to be the home of rabbit-breeding ${ }^{1}$. It is to be noted that neither as regards Gubler's case nor any of the other recorded cases of human hepatic coccidiosis, is there even the slightest evidence of the patient's previous contact with rabbits.

Evidence for his belief in the identity of the intestinal coccidia of man, the rabbit, the dog, and the cat, Leuckart has none, beyond the fact that all the parasites occupy a similar site in their hosts.

It is only fair to acknowledge that Leuckart could hardly be expected to hold correct views concerning the Coccidia, since our knowledge of these organisms-and, in fact, of all the Sporozoa--was both deficient and inaccurate at the time when he wrote. Nevertheless, it is somewhat surprising that his baseless speculations should have been treated with the respect and approval which they have very generally received from later workers.

Rivolta (1873), who had himself studied the coccidia of the rabbit, merely notes the occurrence of similar "psorosperms" in the cat and in $\operatorname{man}^{2}$. He does not express any opinions regarding them. After a further study of Isospora bigemina ${ }^{3}$, however, he attempted a classification of all the coccidia known to him (Rivolta, 1878). He regarded the coccidia of man as distinct from Eimeria stiedae and Isospora bigemina, and named them Cytospermium hominis. He placed I. bigemina in the same genus ("Cytospermium"), but referred the rabbit coccidia to a different one ("Psorospermium"). Although no definitions of his genera are to be found either here or elsewhere in his works, his general conception of the relations of these forms to one another was thus, as far as it went, approximately correct.

Buitschli (1882), in his great treatise on the Protozoa, deals with the early history of the investigation of the Coccidia. He refers to the human cases of infection then known, but does not attempt to identify or classify the parasites. Somewhat later, Balbiani (1884) traverses the same ground. He also alludes to the coccidia found in man, and says they are supposed to be the same as those of animals (rabbits, etc.); but of this he seems doubtful.

Blanchard (1889) deals with the coccidia of man in some detail. He cites correctly the cases of hepatic infection recorded by Gubler and Leuckart, and regards the parasites present in all these as "Coccidium oviforme"-i.e. as

1 "In Frankreich ist bekanntlich die Kaninchenzucht mehr als sonst irgendwo zu Hause" (Leuckart, 1879, p. 280). He then proceeds to draw a fanciful picture of how Gubler's case, "with a certain probability," acquired his infection-by drinking water from an imaginary cistern contaminated by proximity to a hypothetic rabbit-hutch.

2 He refers only to Gubler's case (vide Rivolta (1873), p. 382).

3 See Rivolta (1877, 1877 a).

- The only cases which he mentions are those of Eimer (1870). 
Eimeria siiedae of the rabbit. Virchow's case ${ }^{1}$ he regards as "analogous." $\mathrm{He}$ notes, however, for the first time, that there is a difficulty involved in this supposition : for the oocysts from Dressler's case, as figured in Leuckart, appear to be only about half the length of those found in the liver of the rabbit; whilst the structures described by Virchow were nearly twice as long as the latter. (See Blanchard (1889), p. 48.)

The coccidia found in the human intestine by Kjellberg and Eimer are regarded by Blanchard as "Coccidium perforans" (i.e. as Eimeria perforans of the rabbit's gut). He thus separates them from Isospora bigemina (= "Coccidium Rivolta Grassi, 1881") of the cat. Under the human cases of infection with $E$. perforans he also cites the findings of Rivolta and Grassi. He says: "Rivolta was able to observe coccidia, in the living state, in the excrement of children and adults: in a young boy he found, during nearly three months, that the coccidia were discharged with the dejecta. He found them also in a man afflicted with intermittent fever, and Grassi has published analogous observations" (Blanchard (1889), p. 48). As I have previously pointed out, neither Rivolta nor Grassi really found coccidia in human faeces; and moreover, it seems clear that Blanchard confused with one another the observations of these two workers 2 . Rivolta's "children and adults" appear to be the boy and the young man studied by Grassi (1879), and these are presumably the "analogous" cases which the latter is said to have observed. I have cited this passage from Blanchard in extenso because it seems to me to have been largely responsible for the erroneous statement, which has been so frequently repeated, that Rivolta and Grassi discovered coccidia in the faeces of human beings.

In a later work Blanchard (1896) expresses the same views, but with some change of nomenclature. He still considers the human hepatic coccidia to be the same as those in the rabbit, but calls them "Coccidium cuniculi (Rivolta, 1878)." As human cases he cites those of Gubler, Perls, Sattler, and Silcock. He also still considers most of the intestinal coccidia of man to be identical with the intestinal parasites of the rabbit: but he now names all of themfrom both hosts--"Coccidium hominis (Rivolta, 1878)." The human cases given are Eimer's together with the alleged cases of Rivolta and Grassi once more. He adds Railliet and Lucet's two cases to these, but regards them as doubtful because the site of infection was not ascertained. On the present occasion, however, he says that Isospora bigemina ("Coccidium bigeminum Wardell Stiles, 1891 ") also probably occurs in man. The only human case which he refers to this species is Kjellberg's. The organisms described by Kunstler and Pitres are called "Eimeria hominis R. Blanchard, 1895," and

1 That is, Virchow's (1860) own case-not the case of Kjellberg recorded by him.

2 Blanchard does not specify the works in which he found these observations. The only bibliographic reference to Rivolta is to the second edition (1884) of his "Parassiti vegetali," which I have not been able to consult. It is possible that this differs from the first (Rivolta, 1873), which I have consulted; but from the fact that both contain the same number of pages and plates (according to Stiles and Hassall's Index-Catalogue) this does not seem to me very probable. The explanation of Blanchard's erroneous statement is, $I$ believe, that given above. 
thus included among the coccidia. For reasons which are not given he now regards Virchow's parasites ("pentastome eggs") as "more or less related" to this form.

Blanchard's (1900) more recent account of the coccidia of man is essentially a repetition of that just summarized (Blanchard, 1896).

In his two later works Blanchard makes no reference to his earlier doubts regarding the identity of the hepatic coccidia of man and rabbit. He appears to agree with Ieuckart in regarding all the coccidia of man as identical with those found in other animals. The chief differences between his earlier and later works, and between his and Leuckart's, are merely differences in nomenclature. I have considered these two authors at some length, for their opinions have influenced all later writers-most of whom appear, indeed, to have copied them without verification or criticism.

L. Pfeiffer (1891), in his work on the parasitic Protozoa, mentions the Coccidia of man. The human cases of coccidiosis are, he says (p. 56), given in Leuckart's works: but he records ( $p .57$ ) that the "cysts" of the human parasite have a size ("Masse") of " $56 \mathrm{mmm}$.," citing as his authority one "Dechsler," to whose work he gives no reference. The only explanation which I can suggest of this statement is that Pfeiffer confounded Dressler's case (= "Dechsler's"?), given in Leuckart, with the measurements of Virchow's parasites, as estimated by Blanchard (1889). If we may judge from the rest of his book, a mistake of this sort might quite well have been made by this author. It may be added that he apparently regarded $E$. stiedae, E. perforans, and all the coccidia found in man-both hepatic and intestinal-as belonging to one and the same species.

In his well-known Treatise, Railliet (1895) gives an account of the coccidia of man essentially similar to that of Blanchard. He says Eimeria stiedae " can invade the human liver, as the observations of Gubler, Dressler, Perls and Sattler, von Sommering (Leuckart), Silcock, etc. ${ }^{2}$ show" (p. 138). Eimeria perforans ${ }^{3}$, he says, develops in the intestinal epithelium of the rabbit and man (p. 138); and as human cases he gives Eimer's. He says further that "various observers, among others Grassi, Rivolta, Railliet and Lucet," found coccidia in human faeces. Their site of infection is unknown, and the species to which they belong therefore uncertain: but he considers that the patients studied by himself and Lucet ${ }^{4}$ were probably infected with Isospora bigemina ${ }^{5}$ (p. 140), and that Kjellberg's coccidia were also probably of this species (p. 146). Virchow's own case, he says, is "quite clearly a coccidium," and probably an Eimeria, as also is the organism described by Kunstler and Pitres (p. 133). As we have already noted, this is not at all obvious: in fact, I am

1 "Coccidium oviforme Leuckart = C. cuniculi Rivolta"

2 I do not know who these others are supposed to be, since Railliet appears to have named all the known cases already.

3 "Coccidium perforans Leuckart = C. hominis Rivolta."

4 Railliet and Lucet (1890).

s "Coccidium bigeminum Stiles." 
unable to see any real resemblance between these two organisms and any Eimeria with which I am acquainted.

Labbé (1896), in his first systematic account of the Coccidia, mentions briefly the forms recorded from man. He appears to regard them all as belonging to one species", which he calls "Coccidium hominis Rivolta"; but he says they "strongly resemble $C$. perforans and C. bigeminum," which as also $E$. stiedae--he accepts as distinct species. As describers of " $C$. hominis" he cites Eimer, Rivolta, Leuckart, Virchow (Kjellberg), and Railliet. The organisms of Kunstler and Pitres he considers very doubtful. In his later and more extensive work (Labbé, 1899) he appears to have changed his opinions: for we here find the hepatic coccidia of man referred doubtfully to Eimeria stiedae ("? Coccidium cuniculi Rivolta"), whilst the forms from the human intestine are regarded as a variety of the species occurring in the same situation in the rabbit. He calls them "Coccidium perforans var. Kjellberg," and enumerates the cases of Kjellberg, Eimer, "Grassi, 1880," and Railliet and Lucet, under this heading.

Doflein (1901), and even later in the third edition of his text-book (1911). appears to believe that the hepatic and intestinal coccidia of man both belong to the same species as that occurring in the rabbit's liver ( $E$. stiedae). Infection of the human liver with this species has been, he says, "observed in repeated cases," but he cites-no authorities. He notes further that "some cases of coccidiosis in man" may be due to infection with Isospora bigemina.

The account of the coccidia of man given by Braun $(1903,1906)$, seems to be copied, with a few minor changes and additions, from Blanchard (1.896, 1900). The human hepatic coccidia are regarded as identical with those of the rabbit ("Coccidium cuniculi Rivolta, 1878"-that is, Eimeria stiedae). He cites the cases of Gubler and Silcock, and those recorded by Leuckart'. Virchow's case was possibly infected with the same organism. Kjellberg's case he regards as one of infection with Isospora bigemina ("Coccidium bigeminum Stiles, 1891 "); and he regards Railliet and Lucet's two cases and the "coccidia" of Grunow as possibly coming under the same category. Blanchard's "Eimeria hominis" (Kunstler and Pitres's case) he considers a doubtful form, and he rejects the cases of Jürgens and Thomas.

The intestinal coccidia of man Braun regards, for the most part, as identical with those of the rabbit (Eimeria perforans); and he includes all these in the one species "Coccidium hominis Rivolta, 1878." As human cases he mentions those described by Eimer, and by Railliet and Lucet-the latter, as noted

1 Vide Labbé (1896), p. 545; also his list of hosts and parasites, p. 562.

2 I may note in passing that in the English translation of Braun's work (Braun, 1906, p. 79) there is an amusing mistranslation of a passage dealing with one of Leuckart's cases. We read: "Perls discovered coccidia in an old preparation of Sömmering's agglomerations"--a statement which recurs in the new version of Braun's Animal Parasites, in which the section on the Protozoa has been re-edited by H. B. Fantham. Presumably the translator mistook v. Sömmerring's collection ("Sammlung") of specimens for some kind of pathological accumulation ("Ansammlung") in the liver! 
above, being possibly, however, I. bigemina. "Grassi's and Rivolta's cases" Inay, he thinks, have been infected with the same organism (i.e. E. perforans). Braun (1903, fig. 33, p. 67) gives, moreover, what purports to be a figure of the intestinal coccidia of man. It is labelled "Coccidium hominis (Riv.) in sporulation. (After Riek)." It is, however, in reality copied from the figures given by M. Rieck (1888), whose drawings depict Eimeria perforans from the rabbit 1 .

Minchin (1903) does not discuss the coccidial parasites of man; but in his table of hosts and parasites-which is based upon that of Labbe (1899)-he enters "(?) Coccidium cuniculi (Riv.)" as occurring in the human liver, and "C. perforans var. (Kjellberg 1860)" and "C. bigeminum, Stiles" as inhabiting the human intestine. Later (Minchin, 1907) he merely remarks that "the coccidia. . are alleged to occur in man, but no case of human coccidiosis has yet been satisfactorily investigated" (p. 67). In his latest work on the Protozoa (Minchin, 1912) the coccidia of man are-so far as I can discover-not even mentioned.

Lühe (1906), in his article in Mense's Handbuch, devotes some attention to the coccidia of man. He notices the cases of Gubler, Silcock, Dressler, Sattler, Perls, Eimer, Railliet and Lucet---not failing to add, of course, "the cases of Grassi and Rivolta" -and makes the sweeping statement that "in all these cases probably Eimeria stiedae ${ }^{2}$ was present." It is almost incredible that anybody could thus incorporate the human parasites observed by Dressler, Eimer, and Railliet and Lucet, and the "bodies" found by Rivolta and Grassi, into one common species-the species occurring in the liver of the rabbit. Liuhe's opinion is so obviously untenable, indeed, that further criticism would be superfluous. It only remains to add that he regarded Kjellberg's case as one of infection with Isospora bigemina, though somewhat questionable; and Blanchard's "Eimeria hominis" as a highly doubtful organism.

Bulloch (1907), in Allbutt and Rolleston's System of Medicine, in the main follows Leuckart and Blanchard. He regards the intestinal coccidia of man as Eimeria perforans (called Coccidium hominis) and the hepatic forms as Eimeria stiedae (called Coccidium cuniculi). Under the former he mentions Eimer's and Railliet and Lucet's cases--to which are added the inevitable "cases of Grassi and Rivolta"; and under the hepatic cases those of Gubler, Perls, Dressler, Sattler, and Silcock ${ }^{3}$. Virchow's (own) case is placed doubtfully in the same

1 I mention this because Braun's figures of " $C$. hominis, after Riek" have already been copied as illustrations of the human parasite. They are very misleading, and their identification has given me some trouble. I may note here also that a figure of the "coccidium of man," called merely "Coccidium hominis" (without reference or acknowledgment), is given by Cammidge (1914), and appears to be a considerably retouched imprint from the same original.

2 Lühe gives a list of synonyms of this species, in which he includes Eimeria perforans. I note that "Coccidium perforans Leuck." occurs in it twice, whilst $C$. oviforme Leuckart-perhaps the commonest of all-is omitted. Rivolta's (1878) genus Psorospermium is wrongly given as "Sporospermium."

3 Concerning this case Bulloch adds that it was "an undoubted case of infection with $C$. cuniculi." That it was a case of coccidiosis may be readily admitted, but that the parasites were 
group, but Kjellberg's case is omitted. Bulloch thus regarded all the human coccidia as identical with those of the rabbit ${ }^{1}$.

Brumpt (1913), in his admirable Précis, also follows Leuckart and Blanchard. The hepatic coccidia of man are, he thinks, the same as those of the rabbit-Eimeria stiedae (called "Coccidium cuniculi (Rivolta, 1878)"). As a human case he quotes that of Gubler, and says "Dressler, Perls and Sattler, von Sommering (sic) and Leuckart, Silcock, etc., have recorded other cases." The intestinal coccidia of man he regards as Eimeria perforans (called "Coccidium hominis (Rivolta, 1878)"), citing Eimer's cases as an example; but he adds that Isospora bigemina "has twice been seen in man"-perhaps referring to the cases of Railliet and Lucet. Blanchard's "Eimeria hominis" is described as a "doubtful coccidium."

In the new edition of Kolle and Wassermann's Handbuch there is an article on Coccidiosis by Jollos (1913). He follows Lühe in regarding Eimeria stiedae and $E$. perforans as the same species, and in referring to it all human cases of infection-with the reservation that some may possibly have been infected with $I$. bigemina. He gives no detailed account of the human cases, and does not appear to have inquired into them for himself. Had he done so he could hardly have adopted Luihe's manifestly absurd conclusions.

Now it will be clear, I think, to anybody who considers the opinions of the various authors just enumerated, that-in spite of much difference in matters of nomenclature - there is a general consensus of opinion concerning the identity of the coccidial parasites of man. It is very generally agreed that they are not forms peculiar to man himself, but species which occur usually in other animals--man being regarded as a casual or accidental host. It is thus generally supposed that the hepatic coccidia of man are the same as those commonly found in the liver of the rabbit; and similarly that the intestinal forms found in man are the same as those occurring in the intestine of the rabbit, whilst probably including also those found in the cat and dog. This, as will be evident from what has been said in the preceding section, I take to be a very perverse view of the facts. It appears to me to be a quite unjustifiable tradition which originated at a time when our knowledge of the Coccidia was in its infancy, and which even then had but little real foundation.

But I will leave the discussion of this matter for the moment, and return to it again after considering the new facts, which more modern and competent investigation has brought to light, concerning the coccidia of man.

Eimeria stiedae is far from certain. One may well ask, indeed, whether anybody who saw the case at the time could have named the specific characters of $E$. stiedae: and from Silcock's description it is now impossible for anybody to determine the species of his organisms.

${ }^{1}$ With the exception of the doubtful organism of Kunstler and Pitres ("Eimeria hominis Blanchard"), which is also noticed. 


\section{The Coccidia described from Man in 1915 and later.}

The year 1915 marks a definite advance in our knowledge of the coccidia of man, for towards its close two species were carefully studied and described for the first time by Wenyon. His observations will now be briefly reviewed.

Wenyon's cases. The organisms originally studied by Wenyon (1915, $1915 a$ ) were found in soldiers invalided to England, suffering from dysentery and enteritis, from the Gallipoli campaign of 1915. In the faeces of some of these patients Wenyon discovered structures which were apparently the oocysts of a coccidium. These had previously been found in similar cases by Woodcock (1915) and Low (vide Wenyon, 1915), who, however, did not succeed in identifying them with certainty ${ }^{1}$. But Wenyon was able to observe all the stages of sporulation, and to demonstrate that the species is one which possesses an oocyst containing two tetrazoic spores. He therefore referred the parasite to the genus Isospora, though he did not give it any specific designation.

This coccidium has an oocyst resembling that of Isospora bigemina, but usually smaller, more pellucid and slender, and more delicate in appearance. It is a well-marked species, on the whole, and has since been found and recognized by a number of other observers (Woodcock and Penfold (1916), Roche (1917), Cragg (1917), etc.). A fuller description of the parasite will be given later, in the systematic part of this paper. For the moment it will suffice to note here that none of the later observers has been able to add anything of importance to Wenyon's description of the organism; and none of them has proposed a specific name for $i^{2}$ or assigned it to its proper systematic position. Although it is highly probable, from analogy, that the organism inhabits the epithelium lining the small intestine, this has not yet been actually demonstrated. Up to the present, although over sixty cases of infection have been recorded, the parasite is known only from the stages (oocysts) passed in the faeces. These are, nevertheless, sufficient to establish its svstematic status with certainty.

In a later publication, Wenyon (1915 b) was able to record the discovery of a second coccidial parasite, found in the faeces of a single patient in the same series of cases. This organism was an Eimeria, with small spherical oocysts (about $20 \mu$ in diameter), containing four oval dizoic spores and resembling $E$. falciformis of the mouse. As in the case of his Isospora, Wenyon was able to observe the characters most important for the systematic determination of the parasite, though he gave it no specific name.

1 Woodcock (1915) found only the unsegmented, or partly segmented, oocysts: "for some reason or other no further development has ever been observed." He correctly concluded, however, though on very slender evidence, that "the coccidian is apparently of the Isospora type rather than the Coccidium type."

2 The name Coccidium isospora employed by Savage and Young (1917) I take to be a misprint or lapsus calami. The organism is an Isospora and not a Coccidium (=Eimeria), and cannot be named in this fashion. If the authors' intention was to call the species isospora, then its name-for them-would be Isospora isospora. 
This form also is well defined and easily recognizable: but it appears to be far less common than the Isospora, and, since its discovery, has apparently been found again in other cases by only one observer, Roche (1917). It will be dealt with in greater detail in the systematic section.

Since the publication of Wenyon's observations, I have found the oocysts of another human coccidial parasite in the faeces of a single individual. This organism, like the last-mentioned, is also an Eimeria-having a tetrasporic oocyst and dizoic spores. It differs considerably, however, from Wenyon's parasite; the oocysts being much larger $(36 \mu)$, and the spores long and pointed. I shall reserve a fuller description of it for the next section. I will merely note here that it is a well-defined and undoubtedly distinct form, specifically unlike any other Eimeria hitherto described.

As in the case of the Isospora, so with the two species of Eimeria found in man, it has not been possible as yet to determine the precise site occupied by the parasites in the tissues of their host. It appears highly probable, nevertheless, that they live in the epithelial cells of the mucous membrane of the small intestine. Wenyon's Eimeria is, at all events, so similar to the species infecting the mouse, that it would be expected to have a similar habitat in its host. It is to be remembered that the liver and the large bowel are--if we consider the Coccidia generally - unusual sites of infection in vertebrates.

Before I attempt to reconcile the observations made by Wenyon and later workers with the earlier researches and opinions of others, it will be well to recapitulate the facts recorded in the present section. At the same time I would emphasize a point of importance: namely, that our knowledge since 1915 contains, for the first time, some definite facts. It is no longer merely a mass of fragmentary findings connected by conjecture.

The conclusions which can be drawn from the most recent work are as follows: there are, in man, at least three different coccidia-one species of Isospora and two of Eimeria-whose oocysts are passed in the faeces of infected persons. All three are forms which, during their schizogonic and gametogonic stages, probably inhabit the epithelium of the small intestine. There is, at present, no reason to suppose that these species are not peculiar to man himself.

\section{Discussion and Conclusions.}

It is now possible, after our brief analysis of all the more important facts known about the coccidia of man, to attempt to reduce them to order: and I will therefore indicate how this can be done, and show how the more recently discovered facts can be reconciled with the conflicting statements and views which have hitherto been current.

It will be recalled that in an earlier section (Part I, A) we noted that the observations of the earlier workers indicated that there are at least two different coccidia parasitic in man-one probably an Isospora, inhabiting the intestine, the other an Eimeria, inhabiting the liver. In the last section (Part I, 
C) we have just concluded that the facts more recently brought to light reveal the existence of at least three coccidia in man-one species of Isospora and two of Eimeria, all probably inhabiting the intestine. As regards the occurrence of a species of Isospora in the intestine, therefore, the records are in agreement: and we need have no hesitation, I think, in concluding that Wenyon's Isospora is probably identical with that originally discovered by Kjellberg (Virchow, 1860), and possibly the same as the parasite observed by Railliet and Lucet (1890).

When we attempt to go beyond this, however, the uncertainties increase. Were the coccidia found by Eimer (1870) of the same species? It is impossible to decide with certainty, because we have no description of them. But the nomenclature turns upon this question, because Eimer's coccidia were the first to receive a name-_-"Cytospermium" hominis (Rivolta, 1878). We must either retain this name, applying it to one of the forms now known, or else eliminate it altogether. When names are already in use, and can be applied without violence to known forms, it is, I submit, better to retain them than to replace them by new ones. In the present case, therefore, I propose, since I see no more acceptable solution of the problem, to identify Eimer's parasites with those of Kjellberg; and to suppose that both were the same organism (Isospora) whose oocysts were subsequently studied by Railliet and Lucet, and by Wenyon and others. This coccidium appears to be by far the commonest of those occurring in man: and if, therefore, Eimer, or anybody else, discovered a "coccidium" of which nothing is known but the fact that it inhabited the gut, then it is more likely to have been the Isospora than any other. If this solution be accepted-and for every reason I urge strongly that it should be-then the problems connected with the nomenclature of this organism are immediately simplified, and there is no necessity to introduce any new name. The parasite becomes Isospora hominis Rivolta, 1878, with a long list of synonyms, mostly due to incorrect determination of the speciesa form which can always in the future be easily recognized. I shall adopt this view as that which involves the fewest difficulties and leads to least confusion.

It should be noted here that if Rivolta's name is rejected, on the grounds that the organisms (Eimer's) to which he gave it are not identifiable, then the next name which must be considered is that of Railliet and Lucet (1891). They found what they believed to be an Isospora in human faeces, and named it provisionally $I$. bigemina var. hominis. If we admit that the parasite was specifically distinct from $I$. bigemina - as there is every reason to believethen its name could be arrived at by elevating the variety to specific rank. The coccidium would accordingly be known as Isospora hominis Railliet et Lucet, 1891. The chief difficulty involved in this procedure is, however, the same as that which we encountered in the case of Rivolta's name-the difficulty of determining precisely to what organisms the name was applied. For it is far from certain that the structures which Railliet and Lucet (1890) discovered really were the oocysts of an Jsospora, or even of a coccidium. Their 
description is far from clear, and in some ways even contradictory. Nevertheless, they may, I think, not unfairly be given the benefit of the doubt; and I shall therefore assume that their organisms were the same as those discovered by Kjellberg, seen later by Eimer, and rediscovered and first accurately described by Wenyon. It will be noted that even if we reject Rivolta's name, and accept that of Railliet and Lucet, the name of the organism itself will still be the same-Isospora hominis-differing only in the name of the authority cited for it. The fact that this name should have been twice introduced for parasites possibly identical with Wenyon's, and not certainly identifiable with any other organisms, supplies a sufficient reason, I think, for its retention in
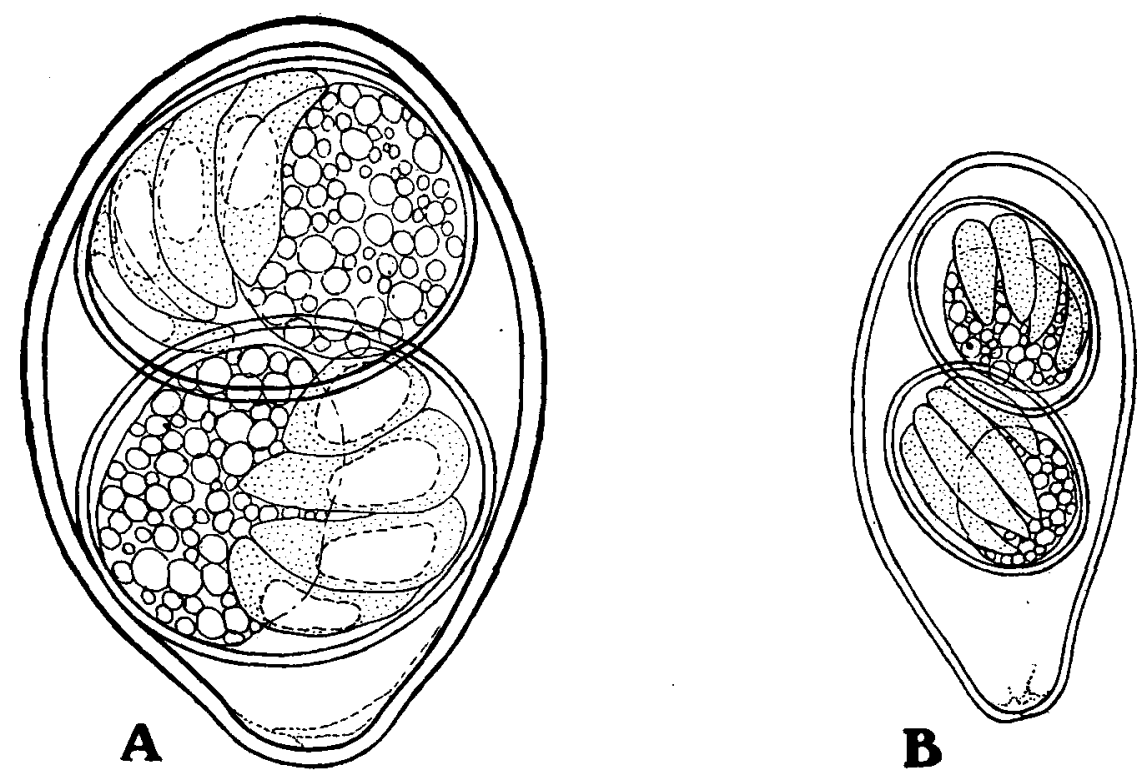

Fig. 1. Fully developed oocysts and spores of Isospora bigemina (A) from cat, and I. hominis (B) from man. Camera lucida drawings. Magnification approximately 2000 diameters.

this sense; whilst to abolish it could serve no useful purpose, and might even lead to greater confusion in the future.

We have already seen that many authors have asserted or conjectured that the Isospora, which they believed to occur in man, is the same as that occurring in cats and dogs 1 -namely, Isospora bigemina. For such a view there is not a vestige of evidence. In appearance the oocysts found in human faeces are quite unlike those from the faeces of the cat (cf. Text-fig. 1, A and B). The latter are usually much larger, though subject to great variation in size; their walls are thicker, and brownisb in colour; and they are plumper and more egg-

1 It may be pointed out that there is still no really conclusive evidence to prove that the Isospora of the cat is the same as that of the dog, or that both are merely varjeties of one species. It is quite possible that they are distinct species. The matter requires further investigation. 
like in their proportions. In comparison with them the oocysts of the human parasite are small, colourless, elongate, and generally more fragile in appearance. It would be almost impossible, I think, for anybody who had carefully compared the forms from the two different hosts to believe that they belong to one and the same species ${ }^{1}$. I have no hesitation, therefore, in concluding that the parasite of man is not Isospora bigemina, but belongs to a separate and well-marked species.

The Isospora of man can therefore be referred without much difficulty to its correct systematic position; and such problems as are raised by its nomenclature, and by the earlier records of buman.coccidiosis, are capable of fairly simple solution. But can the same be said about the species of Eimeria recorded from man? Are the new and old observations equally susceptible of reconciliation? The answer is, as I will now try to show, in the affirmative, in spite of the confusion which appears on the surface.

As we have already seen, the older workers appear to have discovered a species of Eimeria which inhabits the human liver. So far as can be ascertained from the fragmentary records, this organism resembles Eimeria stiedae, the species found in the liver of the rabbit. It is highly probable, however, that it is not this species, notwithstanding the fact that it has, by general consent, invariably been referred to it. No evidence for such a view has ever been brought forward, either experimental or morphological. There is not a particle of proof that the spores of the hepatic coccidia of the rabbit are capable of infecting man, or that those of the parasite of man can infect the rabbit. The allegations ${ }^{2}$ which one constantly meets with in this connexion since the time of Leuckart are wholly without foundation, and there can be little doubt that they are merely text-book traditions of the type familiar to everybody ${ }^{3}$. Leuckart's original reasons for regarding the two forms as identical are too puerile to require further discussion. Moreover, his own work furnishes us with the only extant figures of the human parasite; and these-assuming that they are correct--supply the chief evidenee, from a morphological standpoint, to prove that the hepatic coccidia of man and rabbit belong to distinct species

1 Cf. Wenyon and O'Connor (1917): "The isospora of cats is very common in Alexandria, but the oocysts are quite unlike those of the isospora of man." I may add that Isospora is equally common in cats in London, where even quite young kittens are almost always infected." I have examined more than 100 , and have rarely failed to find oocysts in their faeces-often in enormous numbers.

2 E.g. "Green food-stuffs, contaminated with infected rabbit excrement, are infective to man" (Fantham, 1917).

3 There is a similar tradition, equally devoid of foundation, concerning the "red diarrhoea," or dysentery, of cattle. Many authors assert that this is caused by Eimeria perforans (or E. stiedae) --the coccidium of the rabbit's small intestine (or liver). Even Doflein (1911) in the third edition of his text-book states this as a fact. Nevertheless, there is not a single fact to support such a view, and abundant evidence to refute it. The parasite of cattle, which lives in the large intestine, is morphologically quite unlike $E$. perforans (having small rounded oocysts, for example) and appears incapable of infecting rabbits. There can be no doubt that it is a distinct species $(E$. zürnii Rivolta, 1878) having no connexion whatever with the rabbit coccidia. Cf. Züblin (1908) and other recent works on this subject. 
(see Text-fig. 2, p. 192). It appears highly probable, therefore, that the hepatic coccidium of man is not Eimeria stiedae, but a smaller and similar form which requires further investigation.

The two new species of Eimeria discovered in the faeces of man--that described by Wenyon (1915 b), and the form described in the present paperare still less like $E$. stiedae. They cannot possibly belong to this species ${ }^{3}$, and must be regarded as new. There is, indeed, a possibility that Wenyon's Eimeria is E. falciformis-the species which commonly occurs in the mouse. But there is no evidence to prove this, and it is, I think, preferable to regard the two forms as separate species. There are many good reasons for believing that most of the protozoal parasites of the human bowel are peculiar to mannot forms proper to other hosts, and accidentally acquired by him. Many facts point to this conclusion.

It seems clear, then, that there must be at least four distinct species of coccidia, belonging to two different genera, which are able to parasitize human beings. These are (1) Isospora hominis, already long known, but until the work of Wenyon, ill described; (2) a species of Eimeria discovered by Wenyon, resembling the form found in the mouse, but hitherto unnamed; (3) another species of Eimeria, to be described and named in the present paper; and (4) probably a third species of Eimeria, which, unlike the three intestinal parasites just enumerated, inhabits the liver. This last organism has been seldom seen, imperfectly studied, and incompletely described; so that it is not only unnamed but at present unnamable, because the characters upon which its specific determination depends are as yet unknown.

These conclusions appear to me to be fully justified; and I take them accordingly as a basis upon which to build a systematic account, which now follows, of the coccidia of man.

\section{PART II.}

\section{SYSTEMATIC AND DESCRIPTIVE.}

In this section I propose to give a brief systematic account of the four coccidia of man whose existence has been inferred from the facts analysed in the foregoing pages. I shall describe each species, as far as this is possible in the present limited state of knowledge, of all these parasites, and add such further details concerning their distribution, pathogenicity, etc., as can be gleaned from all available sources.

It has already been pointed out that one of the four parasites to be considered is a species of the genus Isospora, whilst the other three probably all belong to the genus Eimeria. It is necessary, however, to say something more about these two genera, as they offer certain difficulties to the systematist.

1 Cf. figs. 2 and 3, Pl. VIII, and Text-fig. 2, B. 


\section{The genera Eimeria and Isospora.}

Eimeria. This genus is one of the three original genera of coccidia founded by Aimé Schneider (1875). After passing through various vicissitudes, it can now be regarded as firmly established and well characterized. For present purposes, the most distinctive characters of the genus are those supplied by the oocysts and spores of the parasites. Each oocyst contains, when fully developed, four spores, each of which encloses two sporozoites. Coccidium Leuckart (1879) is a synonym of Eimeria, and is the name still preferred by some authors ${ }^{1}$, though indefensible on grounds of priority. The type species of Eimeria is E. falciformis Eimer $(1870)^{2}$, the common parasite of the mouse. The researches of Schaudinn (1900) removed most of the difficulties connected with the genus, which was afterwards firmly re-established by Stiles (1902), and Lühe (1902). It will be unnecessary to enter into further details here.

Isospora. This genus is not so easily dealt with; in fact, it presents several difficulties and cannot even now be regarded as definitively established. The difficulties are due to our present ignorance regarding the type species, and they cannot be decisively removed until this has been reinvestigated.

The genus Isospora was founded by Aimé Schneider (1881) for an organism which, unfortunately, he did not study thoroughly, and of which he has left a very imperfect description. He found the parasite in "a little black slug"he does not say in what organ-which he captured at La Fère (Aisne). He did not record its size. He proposed to call it Isospora rara n.g., n.sp. ${ }^{3}$, but later referred to it himself as Isospora incerta ${ }^{4}$. He characterized the genus (and species) as follows: "psorosperm spherical, as in the preceding genus ${ }^{5}$, with contents undergoing division into two sporoblasts, which develop into two regularly pear-shaped spores, containing pretty numerous sporozoites.". Schneider's figures are hardly more illuminating, though it seems probable from them that the spores each contained approximately four sporozoitesat all events, probably not more than four. It is thus possible to maintain that Isospora denotes, according to Schneider's own definition, a coccidian whose oocyst contains two polyzoic spores: or alternatively, that the oocyst really contained two tetrazoic spores. Subsequent authors have sometimes adopted the first interpretation, sometimes the second. Nobody, however, appears to have found the parasite again; and it offers certain difficulties to

1 Minchin (1912) even goes so far as to say that the proposal to replace the name Coccidium by Eimeria is "contrary to public policy, and should not be followed, anything in the law of priority notwithstanding" (p. 346). I do not agree with this, and I do not believe that public policy is violated by obeying the law in this case. At all events the substitution of names referred to has already been effected by most writers, so that to revert to the name Coccidium now would not only contravene the law, but would also lead to still greater confusion.

2 Called "Gregarina" falciformis by Eimer.

3 Aimé Schneider (1881), p. 401.

4 Op. cit., description of Pl. XXII, figs. 65-72, p. 403.

5 This refers to the genus $K$ lossia Ai. Schn.

- "A corpuscules falciformes assez nombreux." 
those who would look for it. For it is evidently uncommon, it occurs in an unknown organ of a host whose species can only be guessed ${ }^{1}$, and it can only be known, when found, by its resemblance to Schneider's imperfect figures.

Labbé (1893), accepting Isospora as a form possessing two polyzoic spores, introduced the new generic name Diplospora for a coccidial parasite which he had found in birds, and which possessed two tetrazoic spores. In his subsequent works (Labbé, 1896 and 1899) he adhered to this nomenclature: but other workers have considered that Diplospora is a synonym of Isospora, believing Isospora rara to have been also a coccidium possessing two tetrazoic spores. This is the view generally taken, and it has the support of such authorities as Iaveran and Mesnil (1902) and Schaudinn (1900). On the other hand Léger (1911), a great authority on the Coccidia, still prefers to regard Isospora and Diplospora as separate genera, believing that so accurate an observer as Schneider could not have mistaken a tetrazoic for a polyzoic spore. Minchin (1903, p. 232, footnote) has expressed the same opinion.

For my own part I am disposed to assume the standpoint of Laveran and Mesnil (1902) and to regard Diplospora Labbé as a synonym of Isospora Schneider; and I shall follow them, and the majority of recent authors, in referring the coccidia which produce oocysts containing two tetrazoic spores to the genus Isospora. The two best known species of this genus, though neither can be regarded as the type, are the forms generally called $I$. bigemina, from the intestines of cats and dogs, and I. lieberkïhni from the kidney of the frog ${ }^{2}$. The human parasite which I shall refer to this genus-following Wenyon (1915)-bears the closest resemblance to I. bigemina, with which, as we have already seen, it has frequently been confounded.

The coccidial parasites of man can thus be referred to their genera, according to the characters furnished by their oocysts and spores, in the following way:

Genus 1. Isospora Aimé Schneider, 1881. (= Diplospora Labbé, 1893.) Oocyst containing two tetrazoic spores.

Genus 2. Eimeria Aimé Schneider, 1875. (= Coccidium Leuckart, 1879.) Oocyst containing four dizoic spores.

${ }^{1}$ It is sometimes stated that Isospora rara occurs in the kidney, and that its host is Limax cinereo-niger (cf. Doflein, 1911): but these are mere guesses--plausible, no doubt, but still quite unverified.

2 I have already had occasion to note on a previous page that the correct name of "Isospora bigemina Stiles, 1891," is probably I. rivoltae Grassi, 1879. The parasite of the frog was first found by Lieberkühn in 1854 but not named by him. Labbé named it Klossia lieberkühni (in 1894) and later Hyaloklossia lieberkühni (1896, 1899). Laveran and Mesnil (1902) regarded Hyaloklossia as a synonym of Isospora, and therefore called the parasite Isospora lieberkühni Labbé, a name which it has since borne. It appears to have been overlooked, however, that the parasite was possibly first named by Rivolta (1878), who called it Cytospermium ranae. Its correct name therefore would be Isospora ranae Rivolta, 1878. I may also note here that it is possible to regard Cylospermium as the "correct" name of the genus here called Isospora, and to regard the parasite of the frog as its type. My own view is that it is far better to eliminate Cytospermium altogether, on the grounds that it was never defined, and included a heterogeneous assemblage of forms. 
The species of human parasites belonging to these two genera will now be named and described as far as is possible.

(1) Isospora hominis Rivolta, 1878 (emend.).

Psorospermien (Kjellberg's), Virchow, 1860.

Psorospermien?, Leuckart, 1863.

Psorospermien, Eimer, 1870.

Cytospermium hominis Rivolta, 1878.

Coccidium perforans Leuckart, 1879.

Coccidien, Psorospermien, Bütschli, 1882.

Coccidium perforans (Leuckart) Blanchard, 1889.

Coccidies intestinales, Railliet et Lucet, 1890.

Coccidium bigeminum var. hominis Railliet et Lucet, 1891.

\begin{tabular}{l|l} 
Coccidium bigeminum (Stiles) p.p. \\
Coccidium perforans (Leuckart) p.p.
\end{tabular}

Coccidium hominis (Rivolta) Labbé, 1896.

$\left.\begin{array}{l|l}\text { Coccidium hominis (Rivolta) p.p. } \\ \text { Coccidium bigeminum (Stiles) p.p. }\end{array}\right\}$ Blanchard, 1896.

Coccidium perforans var. Kjellberg, Labbé, 1899.

Coccidium hominis (Rivolta) p.p. $\quad$ Blanchard, 1900.

Coccidium bigeminum (Stiles) Doflein, 1901.

$\left.\begin{array}{l}\text { Coccidium perforans var. (Kjellberg) p.p. } \\ \text { Coccidium bigeminum (Stiles) p.p. }\end{array}\right\}$ Minchin, 1903.

Coccidium hominis (Rivolta) p.p.

Coccidium bigeminum (Stiles) p.p. $\}$ Braun, 1903.

Eimeria stiedae (Lindemann) p.p. $\}$ Lühe, 1906.

Isospora bigemina (Stiles)? p.p.

Coccidium hominis (Rivolta) Bulloch, 1907.

Isospora bigemina (Stiles) Doflein, 1911.

Coccidium hominis (Rivolta) p.p.

Coccidium bigeminum (Stiles) p.p.

Brumpt, 1913.

$\left.\begin{array}{l}\text { Eimeria stiedae (Iindemann) p.p. } \\ \text { Isospora bigemina (Stiles)? p.p. }\end{array}\right\}$ Jollos, 1913.

Coccidia, ? Isospora, Woodcock, 1915.

Isospora, Wenyon, 1915.

Coccidium (Isospora) Wenyon, 1916.

Isospora, Woodcock et Penfold, 1916.

Isospora sp. Dobell, 1916.

Isospora sp. Dobell, 1917.

Isospora sp. Dobell èt Stevenson, 1917.

Isospora, Roche, 1917.

Coccidium (Isospora) Wenyon et O'Connor, 1917.

Isospora, Cragg, 1917. 
Isospora bigemina var. hominis (Raill. et Luc.) Fantham, 1917.

Coccidium isospora Savage et Young, 1917.

Coccidia (isospora), Martin, Kellaway et Williams, 1918.

Coccidium (Isospora sp.) Boney, Crossman, et Boulenger, 1918.

(See Pl. VIII, fig. 1, and Text-fig. 1, B, p. 177.)

The history of our knowledge of this parasite has already been dealt with in some detail. So far as I can judge it was originally discovered by Kjellberg, about 1860 , in the villi of the small intestine. It was then seen-probably, but not certainly--though not named, by Eimer (1870); and first named, but not seen, by Rivolta (1878). Railliet and Lucet (1890) possibly found its oocysts in the faeces for the first time, but this is somewhat doubtful; and Rivolta and Grassi certainly did not find them, though often alleged to have done so. The first correct and clearly recognizable account of the oocysts and spores is that of Wenyon $(1915,1915 a)$. Drawings of these have been published by Wenyon (1915 $a, 1915 c)$ - the latter work containing also some good photographs of the oocysts, taken by Dr A. C. Stevenson. Since the appearance of Wenyon's description over fifty cases of infection with this organism have been recorded.

The schizogonic cycle of development in the intestine has yet to be investigated $^{1}$. It is doubtless closely similar to that of $I$. bigemina in the dog and cat. The organism is accurately known, up to the present, only from its oocysts in human faeces. They are elongate ovoid in form, the narrow end being usually somewhat drawn out into a sort of neck. They vary in length from about $25 \mu$ to $33 \mu$; their width, at the widest part, being about half their length (ca. $12 \cdot 5 \mu$ to $16 \mu$ ). The relative dimensions of the oocysts are not constant, however, though they are much oftener long and slender than short and plump. (See Plate VIII, fig. 1, and Text-fig. 1, B.) The oocyst wall (oocyst proper) is clear, colourless, and porcellaneous in appearance. It consists of at least two-and probably more-layers, and is impervious to most fixing fluids. A micropyle is probably present at the narrower end of the oocyst, but it is inconspicuous.

The oocysts of $I$. hominis, like those of I. bigemina, are usually discharged from the body in an unsegmented condition (cf. fig. 1, Pl. VIII), though occasionally oocysts already containing two sporoblasts may be found in the freshly passed faeces. Development of the spores takes place outside the host, and requires several days for its completion. In this respect Isospora hominis differs conspicuously from the two species of Eimeria to be next described. At the time of its ejection from the body of the host, the oocyst generally has its protoplasmic contents contracted into an almost spherical mass, filled with brightly refractile granules. A clear area amidst these is often discernible, and probably represents the nucleus. (Cf. fig. 1, Pl. VIII.)

1 The statements concerning the schizogony, fertilization, etc., of this form, made by Wenyon $(1915 a)$, are presumably inferences from what is known of the development of allied forms. 
Outside the human body, the protoplasm of the oocyst segments into two round sporoblasts which soon become ovoid and develop into spores, which are similar in structure to those of other species of the genus. The spore measures about $12 \mu$ to $14 \mu$ in length, $7 \mu$ to $9 \mu$ in breadth. The sporocyst is fairly thick, and contains, when the spore is mature, the four vermiform sporozoites characteristic of the genus, and a large granular sporocystic residue. (Cf. Text-fig. 1, B.) Very frequently one or two small and irregular bodies are to be seen at the narrower end of the oocyst. They are present before the segmentation of its contents (cf. fig. 1, Pl. VIII), and therefore do not represent a true oocystic residuum, which is absent in $I$. hominis. The sporozoites are long and narrow. Their internal structure is difficult to make out, but each probably possesses a nucleus situated subterminally.

Wenyon and O'Connor (1917) have recorded that an abnormal development may sometimes occur in which the oocyst forms "only a single sporocyst containing 8 sporozoites." I have seen a similar abnormality very rarely in I. bigemina from the cat.

Occurrence. The oocysts of this species were found by Wenyon (1915) in the faeces of patients invalided to England from Gallipoli, and suffering from dysentery and other intestinal ailments. They had previously been noticed in the same class of cases by Woodcock (1915) and Low (vide Wenyon, 1915). Wenyon found altogether fifteen infected cases among 556 examined (Wenyon, 1916); and one further case was subsequently found in completing the examinations of this whole series of 775 patients (Dobell and Stevenson, 1917). Woodcock (1915) and Woodcock and Penfold (1916) have recorded in all ten further infections found in the same class of cases ${ }^{1}$, and I have recorded one (Dobell, 1916). All the infected persons had served in the Eastern Mediterranean War Area; and most, if not all, of them had been on the Gallipoli Peninsula. Somewhat later Roche (1917) found fifteen Isospora infections among 893 patients suffering from dysentery and diarrhoea at Salonika. Wenyon and O'Connor (1917) record a case found in Egypt, and note that "it seems probable that the infection came from Gallipoli." Savage and Young (1917) found six cases, out of 1088 men examined, among troops who had mostly served in Egypt, Gallipoli, Mesopotamia, and Salonika. Another case is recorded in Egypt by Martin, Kellaway, and Williams (1918), who examined 422 patients suffering from diarrhoea and dysentery. Cragg (1917) found four cases of infection among 613 patients-invalided for "dysentery and allied complaints" from Mesopotamia-whom he examined in Bombay: and Boney, Crossman, and Boulenger (1918) have quite recently stated that among 890 British patients with dysentery and other intestinal disorders,

1 The two patients passing "coccidian cysts" recorded from Manchester by Williamson (Journ. Roy. Army Med. Corps, 1917, xxvII, p. 451), and the four patients in Liverpool infected with "Coccidia (apparently Isospora type)" mentioned by Fantham (Lancet, 10 June, 1916), probably belong to the same category. The patients were men from Gallipoli, but their infections were not accurately diagnosed. Cf. Dobell (1917): 
examined at a base hospital in Mesopotamia, they found seven infected with Isospora. Finally, $\mathrm{O}^{\prime} \mathrm{Connor}^{1}$ has found nine more infected cases in Egypt and Sinai among British troops and natives, of whom he examined some 3800 in 1916 and 1917.

Castellani (1917) states that "coccidiosis is, comparatively speaking, common in the Balkans," and mentions that he has seen "six cases, all in Macedonia." It is possible that these too were Isospora infections, but in the absence of any further information it is impossible to ascertain what organisms he studied.

Sangiorgi (1918) has quite recently described a case-a soldier suffering from nephritis-in which he believes he has found Isospora bigemina. The oocysts were found in the faeces, and bodies interpreted as schizogonic stages in the urine. It seems probable that this patient was really infected with I. hominis, though from the dimensions of the parasites-if they are correctly stated - this is doubtful. They can hardly have been I. bigemina, as the author believes. The "stages" found in the urine seem also open to question.

It will thus be seen that about seventy cases of infection with Isospora hominis have now been definitely recorded: and to this list several doubtful cases, both ancient and modern, should possibly be added. It is noteworthy that all the infections recorded since 1915 have been found in men who had been in Egypt, Gallipoli, Salonika, or Mesopotamia. The "dysentery" cases invalided to England from Gallipoli in 1915 showed a fairly high percentage of infection with I. hominis-2.7 per cent. in Wenyon's (1916) original seriesbut since then the infection has apparently disappeared in this country, even from among the same class of cases. At all events, I have not found the oocysts of Isospora in the faeces of any patients from Gallipoli or elsewhere since 1916, and inquiries which I have made of others have likewise failed to elicit a single case of infection in the patients invalided to this country during the last two years.

In most of the cases infected with Isospora the infection appears to have been small and transitory. An extreme instance is a case studied by Dr Stevenson and myself (1917), in which the stools were examined-sometimes most exhaustively —on six occasions, and only a single oocyst was ever found. Heavy infections appear to be uncommon, but have been found by Wenyon (1916), Roche (1917), Cragg (1917), and O'Connor. Roche (1917) states that "as a rule these parasites disappeared within a few days, but in one patient they were found in daily examinations for three weeks."

Pathoginicity. There is, up to the present, no proof that $I$. hominis is a pathogenic parasite. Since it is, like all other coccidia, an organism which lives at the expense of the tissues of its host, it is clear that it may be able to produce a pathological condition: nevertheless, even in the most heavily infected cases,

1 Capt. F. W. O'Connor, R.A.M.C., has very kindly permitted me to record this and other information (contained in the present section, and attributed to him) from his still unpublished work. 
no clinically recognizable "coccidiosis" due to this parasite has yet been described. It is true that the oocysts have generally been found in the faeces of patients suffering, or who had recently suffered, from dysentery or diarrhoea; but this is probably merely because the faeces of persons with no intestinal ailments are not usually examined. When symptoms of intestinal disorder have accompanied the infection, they have generally been attributable to other causes. Cragg (1917), for example, records two fatal cases in which "there was a very heavy infection" with Isospora. One died from "the rupture of an old dysenteric ulcer," and Entamoeba histolytica was found in the stools: the other succumbed to bacillary dysentery--Shiga's bacillus having been isolated before death. He concludes that in both these cases "there was other adequate cause for the patient's condition, and no indication of the pathogenicity of the Coccidium." Post mortem examinations were made of both these cases, but unfortunately nothing is recorded concerning the state of the patients' small intestines ${ }^{1}$.

In this connexion the case which I found (1916) at Walton Hospital may be mentioned. The patient was not suffering from any intestinal ailment, though he had had diarrhoea on the Gallipoli Peninsula in the previous year. He was in hospital for varicocele, and was one of the series of seventy nondysenteric patients whose stools I examined for protozoal infections. No infections with Isospora were discovered among the 130 patients with intestinal ailments examined at the same hospital.

Treatment. No method of treatment has yet been discovered which will get rid of an Isospora infection-or, for that matter, of any coccidial infection in any animal. Emetine appears to be the only drug which has hitherto been tried. Wenyon and O'Connor (1917) treated an infected patient with emetine hydrochloride-administered hypodermically and by the mouth simultaneously-and record that the oocysts disappeared from the stools during treatment and were not found again for a month following. But $O$ 'Connor has since treated two more cases with emetine, and found that the drug was without effect. Similar observations are recorded by Savage and Young (1917). Moreover, it is to be noted that the oocysts of this parasite have several times been first found in the stools after the patients had been treated with emetine : and it is not uncommon for them to disappear completely without any specific treatment.

Attempts to infect animals experimentally. Several attempts have been made to infect animals other than man with $I$. hominis, but without success ${ }^{2}$.

1 Cragg (1917), for some reason which is not apparent, seems to have supposed that Isospora hominis inhabits the liver. He mentions that "nothing unusual was found in the liver" in one case; and says of the other, "unfortunately the liver was not examined." So far as I am aware, an Isospora which inhabits the liver has not yet been discovered.

2 Fantham (1917) has recently claimed to have infected kittens with $I$. hominis, and says he produced in their intestines a "condition resembling that seen in the human intestine examined post mortem." This, however, has never been described, so far as I am aware; and the statement can hardly be accepted without some concrete evidence to support it. 
Wenyon and O'Connor (1917) fed kittens and a mouse on the ripe spores, but none of them became infected. Subsequently O'Connor made a very carefully controlled experiment with two young puppies, but he was unable to infect either. Attempts of this sort are not easily carried out, as both puppies and kittens are frequently found in nature already infected with a species of Isospora of their own. Up to the present, therefore, there is no evidence to show that $I$. hominis can parasitize any host but man.

(2) Eimeria wenyoni n. sp.

Eimeria (Coccidium) Wenyon, $1915 b$.

Coccidium (Eimeria) Wenyon, 1916.

Eimeria sp. Dobell, 1917.

Eimeria sp. Dobell et Stevenson, 1917.

Eimeria Roche, 1917.

(See Plate VIII, fig. 2.)

I have named this species in honour of its discoverer, who has given us the only description which we possess of the parasite'. It is possible, however, that the coccidia found in man by Eimer (1870) were of this species; and if so, then this is the organism which Rivolta (1878) named Cytospermium hominis, and to which other names have since been given. We have previously decided to regard Eimer's coccidia as Isospora however, so that it will suffice merely to note this possibility here. It will be unnecessary to add a long list of conjectural synonyms.

This species is known only from its oocysts, which are similar to those of E. falciformis ${ }^{2}$. They are passed in the faeces in a fully developed condition, with the spores and sporozoites already differentiated. (Cf. fig. 2, Pl. VIII.)

The oocyst is approximately spherical, with a diameter of about $20 \mu$. Itsouter surface is rough and rugose, its inner smooth and lined with a delicate membrane. The four spores which lie within it are oval, and measure about $10 \mu$ by $7 \mu$. The external surface of the sporocyst is rough and irregular (probably from the presence of adherent remains of the epispore). There is no oocystic residual body. Each spore contains two typical sporozoites, lying with their blunter ends directed towards opposite poles, and one or two highly refractile masses (sporocystic residua).

Wenyon (1916) found this coccidium in small numbers in a sample of faeces from a single case out of 556 whose faeces he examined. The patient was among those invalided to England from Gallipoli (in 1915) suffering from "dysentery" or intestinal derangement, and was No. 242 in the series of cases studied at the London Hospital. In completing the examination of this series-- 775 cases in all-no other infections with this organism were discovered (Dobell and Stevenson, 1917): nor was its presence in the faeces recorded by any other

1 'The description of the organism here given is taken from Wenyon's account $(1915 b)$.

'The oocysts of $E$. falciformis are, however, typically somewhat oval, and not spherical. 
worker engaged in the study of the same class of cases in this country (cf. Dobell, 1917) ${ }^{1}$.

Since the publication of Wenyon's original and only case, the parasites have been found again-so far as I have been able to ascertain with certainty -by only one observer. This was Roche (1917), who found three cases of infection among 893 military patients, all suffering from dysentery or diarrhoea, whom he examined at Salonika. The parasites were recorded merely as "Eimeria"; but Captain Roche, in answer: to my inquiries, kindly informed me that they were, so far as he could judge, identical with the forms described by Wenyon.

There are thus only four cases of infection with this organism known up to the present; and when the very large number of persons examined is taken into account, it must therefore be regarded as extremely rare. Of its pathogenicity nothing is known, and methods of specific treatment for the infection are still untried. It is possible that a severe infection may give rise to an enteritis, since the habitat of the parasite is probably the mucous membrane of the small intestine: but if we exclude the highly doubtful cases of Eimer (1870) the organism has not yet been found in the tissues, and the fact that the recorded cases of infection were found among patients suffering from intestinal complaints is probably without significance. Our knowledge of the geographical distribution of the parasite is limited to the fact that hitherto it has only been recorded in persons from the Eastern Mediterranean region.

(3) Eimeria oxyspora n. sp.

(See Plate VIII, fig. 3.)

I propose this name for a coccidial parasite whose oocysts I have found in human faeces, and which has not been previously described. As in the case of $E$. wenyoni there is a remote possibility that this is the organism which was seen in the intestine by Eimer (1870); but there is nothing to support such a supposition. And of the other coccidia previously recorded there is none which can be regarded with any plausibility as belonging to this species.

Up to the present $I$ have found this organism in the faeces of a single individual only. The patient is a young man who has been in South Africa, Ceylon, and India, and has suffered since 1912 from amoebic dysentery of a chronic relapsing type, which has hitherto proved extremely refractory to every kind of treatment. He has been for some time under the care of my friend Dr G. C. Low (now Temporary Major, I.M.S.), with whom I have studied his amoebic infection. A brief account of the case from this standpoint has already been published. (Vide Low (1918), Case 2, "B. W.," p. 164.) I have made an exhaustive examination of the stools of this patient (on over forty occasions in the course of the last year) but have found the coccidial parasite in them only twice, and then in extremely small numbers.

1 The "Eimeria sp." noted by Dobell and Stevenson (1917) and Dobell (1917) both refer to Wenyon's original case. 
The oocysts are passed in the faeces with their contents already completely differentiated. In this respect, therefore, they resemble those of $E$. wenyoni and differ from those of $I$. hominis. In almost every other way, however, they are strikingly different from those of $\boldsymbol{E}$. wenyoni--and, in fact, from those of every other species of Eimeria with which I am acquainted. The oocyst (Plate VIII, fig. 3) is spherical, with a diameter of about $36 \mu$. Its wall is composed of at least two distinct layers--an inner, fairly thick and uniform, and an outer which appears composite, and is incrusted with adherent bacteria and other foreign particles from the faeces. The wall as a whole is faintly yellow in colour, but is quite transparent, so that the entire contents of the oocyst can be very clearly seen.

The oocyst contains, in addition to the four dizoic spores characteristic of the genus, a small oocystic residue composed chiefly of very brightly refractile granules, which may be more or less dispersed. The spores themselves are long and sharply pointed at both ends, their shape being like that of a whetstone. Their length is $30 \mu-32 \mu$, and their width in the middle about $7 \cdot 5 \mu$. The sporocyst is composed, as usual, of a tough and uniform inner coat (endospore) and a deciduous thin outer membrane (epispore). The remains of the latter give the external surface of the spore a slightly uneven or frilled appearance, noticeable chiefly towards the extremities.

The two long and slender sporozoites lie within the spore, which they almost fill, in the typical manner, with their anterior ends ${ }^{1}$ directed towards opposite poles. The anterior end of each is pointed, and wrapped round the posterior end of its fellow. The posterior end is rounded, and contains an oval body, lying subterminally, which is probably the nucleus. Between the latter and the posterior extremity there are always present two or three very bright and small bodies ${ }^{2}$, fusiform in outline and longitudinally disposed. (Cf. fig. 3, Pl. VIII.) A few small and rather feebly refractile granules lie anterior to the nucleus and extending for a short distance forwards along the body of the sporozoite. There is a relatively small sporocystic residue, represented by a few bright and scattered granules lying near the middle of the spore.

The foregoing account is based upon a careful study of the living oocyst, as I have not been able to obtain any stained preparations. All the structures described are, however, easily made out in the living organisms; and they are shown, as accurately as possible, in fig. 3, Pl. VIII. Dr A. C. Stevenson, of the Wellcome Bureau, kindly photographed the oocyst from which this drawing was made. Unfortunately, however, the object is a very unsuitable one to photograph, as the spores all lie in different planes, and consequently cannot all be shown clearly at the same time. The photograph, though forming a

\footnotetext{
1 I use these terms-anterior and posterior-for the ends which appear to correspond to the fore and hind extremities of other coccidial sporozoites which $I$ have been able to study in greater detail-especially those of Aggregata and Adelea.

2 I do not remember to have observed similar structures in the sporozoites of any other coccidium. I do not know what they are. They have a very bright and almost crystalline appearance.
} 
permanent record, was therefore thought not so suitable for reproduction here as a carefully executed drawing.

I can add nothing regarding the pathogenicity of $E$. oxyspora. The patient in whose faeces the parasites were found has a very heavy infection with Entamoeba histolytica, and a small infection with Ankylostoma. The Eimeria infection was so small that, even if it had caused any clinical symptoms, it would hardly have been possible to distinguish these from the effects produced by the accompanying parasites. At present there is no indication that $E$. oxyspora is pathogenic; though since it is, like all other coccidia, a tissueparasite, it is doubtless capable of doing damage to its human host. From analogy with other forms, one would expect that the habitat of the parasite is the epithelium of the small bowel; and therefore that the effects, if any, of its presence would be manifested as an enteritis.

It is perhaps worthy of mention that, as in the case of Isospora, it is probable that the administration of emetine has no curative effect upon an infection with this organism: for the case infected had already received large quantities of emetine, both hypodermically and per os, before the parasites were found in his faeces.

(4) Eimeria (?) sp., the hepatic coccidium of man.

"Cellules ovoïdes, ? œuf's d'helminthes," Gubler, 1858.

"Corps oviformes," Davaine, 1860.

"Psorospermien," Leuckart, 1863.

"Psorospermi," Rivolta, 1873.

Coccidium oviforme Leuckart, 1879.

"Coccidien," "Leberpsorospermien," Bütschli, 1882.

Coccidium oviforme? (Leuckart) Balbiani, 1884.

Coccidium oviforme (Leuckart) Blanchard, 1889.

Coccidium oviforme (Leuckart) Silcock, 1890.

(loccidium oviforme (Leuckart) Railliet, 1895.

Coccidium cuniculi (Rivolta) Blanchard, 1896.

Coccidium cuniculi? (Rivolta) Labbé, 1899.

Coccidium cuniculi (Rivolta) Blanchard, 1900.

Coccidium cuniculi (Rivolta) Doflein, 1901.

Coccidium cuniculi (Rivolta) Braun, 1903.

Coccidium cuniculi? (Rivolta) Minchin, 1903.

Eimeria stiedae (Lindemann) Lühe, 1906.

Coccidium curiculi (Rivolta) Bulloch, 1907.

Eimeria stiedae (Lindemann) Doflein, 1911.

Coccidium cuniculi (Rivolta) Brumpt, 1913.

Eimeria stiedae (Lindemann) Jollos, 1913.

(See 'T'ext-fig. 2, A.) 
This species is added here chiefly for the purpose of directing attention to our ignorance of it. Hitherto it has been wrongly regarded as identical with the species which occurs in the liver of the rabbit (Eimeria stiedae).

Altogether there are but five recorded cases of infection with this organism; namely, the cases of Gubler ${ }^{1}$ (1858), Dressler (Leuckart, 1863, 1879), Perls and Sattler (Leuckart, 1879), Perls and von Sömmerring² (Leuckart, 1879), and Silcock (1890). These were recorded respectively in Paris, Prague, Vienna, Giessen, and London. Gubler and Silcock have given some account of their patients: of the others practically nothing is known. Gubler has described the parasites-in the language of his dav, and in ignorance of their nature--and Davaine (1860), Silcock, and Leuckart have noted their resemblance to $E$. siiedae. Dressler's rude sketches of the oocysts which he found have been reproduced by Ieuckart $(1863,1879)$. Beyond these fragments nothing of any value can be gleaned concerning the coccidia themselves.

That the hepatic coccidium of man displays a general resemblance to E. stiedae seems probable from the testimony of Gubler, Davaine, Leuckart, and Silcock. We learn from the first that the oocyst is ovoid. This is confirmed by Dressler's drawings and Silcock's description, and is implicit in Leuckart's account. Gubler further noted the presence of a micropyle at one end of the oocyst. Nobody, however, has recorded the size of the latter; but from Dressler's drawings - the magnification of which is given by Leuckart- - it is evident that its length is about $20 \mu$. It thus appears that the oocysts of the human hepatic coccidium are much smaller than those of Eimeria stiedae; and this is confirmed by Davaine (1860), who expressly states that they resemble the smaller forms found in the rabbit's liver ${ }^{3}$. Silcock alone seems to have seen the formation of spores within the oocyst. The other observers saw only the oocysts with unsegmented contents. But Silcock gives no description of the sporulation, and does not state how many spores and sporozoites were formed. He appears, however, to have believed that the human coccidium is similar, in these respects, to Eimeria stiedae as described and figured by Leuckart. Perhaps it may be concluded from this that the human parasite is also an Eimeria. Beyond this it would be rash to draw any conclusions as to its systematic status.

Dressler's drawings, as reproduced by Leuckart, apparently show four oocysts seen under a low magnification (330 diameters), in which little can be made out; and two larger (mạgnified 1000 diameters) which are apparently

1 Gubler was the original discoverer of the organism.

2 This case, as already noted, is very doubtful; nor is there much to support the one preceding it. They are cited here on the authority of Leuckart—not a very convincing authority where the Protozoa are concerned.

3 The oocysts of $E$. stiedae are commonly $35 \mu-37 \mu$ in length. I have never seen any measuring less than $30 \mu$. It is noteworthy that Leuckart himself gives figures of $E$. sliedae, magnified 550 diameters (1879, fig. 106, p. 256), which are approximately equal in size to those which he gives of the human parasite (Dressler's figure, Fig. 114, $b$ and $c$, p. 281) stated to be enlarged 1000 diameters.

Parasitology xI 
oocysts with unsegmented contents-one of them degenerate and breaking up, the other with its contents contracted from the cyst. I have copied this last figure (Text-fig. 2, $A$ ), and give beside it (Text-fig. 2, $B$ ), an outline of a typical oocyst of Eimeria stiedae at a similar stage and the same magnification. Even when every allowance is made for differences of technique in draughtsmanship, it is difficult to believe that the objects from which these drawings were made were identical, or even strikingly alike. To me it seems certain that if Dressler's drawings were even only approximately correct, then the hepatic coccidium of man cannot be Eimeria stiedae. How it comes about that all authors, for some forty years, have unanimously declared the two organisms to be identical, is a mystery which need not be discussed further here ${ }^{1}$.

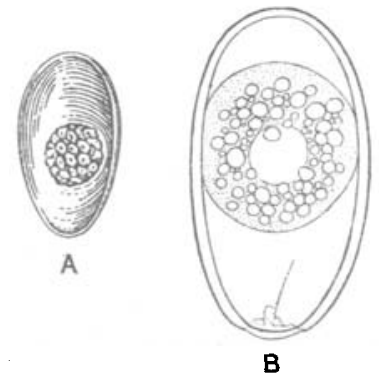

Fig. 2. A, oocyst, with unsegmented contents, of human hepatic coccidium. (From Leuckart, after Dressler.) B, oocyst of Eimeria stiedae, from gall bladder of rabbit: stage in development similar to A. (Drawn with camera lucida.) Both magnified approximately 1000 diameters.

From the statements of Gubler, Leuckart, and Silcock, it seems justifiable to conclude that the lesions produced by the human parasite resemble those seen in the rabbit, and caused by $E$. stiedae. Silcock's account, if correct, appears to indicate that the human parasite may also invade the spleen $^{2}$, and possibly the gut. The clinical picture of human hepatic coccidiosis-as presented by Gubler and Silcock-shows no particularly striking features. The condition is manifested, as might be expected, by enlargement of the liver, fever, and digestive derangements. It may be noted that the condition of Gubler's case was diagnosed before death as due to a hydatid eyst; whilst Virchow (1860), from Gubler's description, regarded it as probably a case of cancer, and Giles (1890) notes that it "reads suspiciously like one of ankylostomiasis."

From the information available I conclude that there is probably a coccidial parasite which occurs very rarely in the human liver; that it resembles Eimeria stiedae, but is considerably smaller, and probably belongs to the same genus, but to a distinct species; and that there is no evidence that Eimeria stiedae has ever been found in the human liver, or that this species can infect $\operatorname{man}^{3}$. It is clear that further observations alone can solve the problems connected with the human parasite, and the naming

\footnotetext{
1 The explanation is doubtless that given by Bacon, in another connexion, some three hundred years ago. "For as things now are, if an untruth in nature be once on foot, what by reason of the neglect of examination, and countenance of antiquity, and what by reason of the use of the opinion in similitudes and ornaments of speech, it is never called down." Adv. Learn., I, 1 (3).

2 So far as I am aware, $E$. stiedae has never been found in this situation in the rabbit.

${ }^{3}$ It has been stated by Fantham (1917) that cases of infection with Eimeria stiedae have recently occurred "among patients from the Eastern war zones." I can find no authentic records to justify this statement, and the figure of "Eimeria stiedae" which accompanies it will hardly serve to carry conviction to those familiar with this organism.
} 
of it may therefore be left to some future investigator who is fortunate enough to find it once more ${ }^{1}$.

\section{SUMMARY AND GENERAL CONCLUSIONS.}

From a study of the organisms themselves, so far as this has been possible, and from an analysis of all accessible records relating to them, I conclude that there are four distinct species of coccidia which may parasitize man. These are: (1) Isospora hominis Rivolta, 1878 (emend.), discovered by Kjellberg in 1860, and recently investigated by Wenyon; (2) Eimeria wenyoni n.sp., a form discovered in 1915 by Wenyon; (3) Eimeria oxyspora n.sp., another new form, here described for the first time; (4) an undetermined species of Eimeria (?) which was discovered by Gubler in 1858. This last inhabits the human liver, whilst the three others probably live in the small intestine. Probably some seventy cases of infection with the Isospora have now been seen, mostly in persons who have been in the Near East; but the other parasites appear to be extremely rare, and little is known concerning their probable geographical distribution.

All these parasites are probably peculiar to man. There is no evidence that any of them is or can be parasitic in any other host. The prevailing belief that the coccidia of man are identical with those of rabbits, cats, or dogs, is therefore unfounded. Furthermore, there is as yet no good evidence to show that man may harbour any species of coccidia other than the four just enumerated. All these forms, however, require fuller investigation. They are here briefly and incompletely described from the data at present available.

There is at present no proof that the coccidia of man--with the probable exception of the species occurring in the liver-can produce a clinically recognizable pathological condition of "coccidiosis": and as yet no method of treatment which will eradicate an infection with any species has been discovered.

London, August 1918.

\footnotetext{
1 As it seemed possible that specimens or preparations from the case studied by the late Dr Silcock might still be in existence at St Mary's Hospital, my friend Capt. S. R. Douglas, I.M.S. (ret.), very kindly instituted inquiries on my behalf, and searched through the records and material in the Pathological Department. His efforts unfortunately were unavailing, but I take this opportunity of thanking him again for his help in the matter. Up to the present, therefore, I have had no opportunity of studying the parasites themselves from any case of human hepatic coccidiosis.
} 


\section{BIBLIOGRAPHY.}

Balbiani, G. (1884). Leçons sur les Sporozoaires. Paris.

Blanchard, R. (1889). Traité de Zoologie Médicale (Vol. r.). Paris.

(1896). "Parasites animaux," in Bouchard, C. Traité de Pathologie générale, II. 649. Paris.

(1900). Les Coccidies et leur rôle pathogène. Caus. Scientif. Soc. Zool. France, I. 133.

BoEck, C. (1891). Vier Fälle von Darier'scher Krankheit. Arch.f. Dermatol. u. Syph. xxIII. 857.

Boney, T. K., Crossman, L. G. and Boulenger, C. L. (1918). Report of a base laboratory in Mesopotamia for 1916, with special reference to water-borne diseases. Journ. Roy. Army Med. Corps, xxx. 409.

Braun, M. (1903). Die thierischen Parasiten des Menschen. III Aufl. Würzburg. (1906). Animal parasites of man. 3rd ed. English translation. London.

Brumpt, F. (1913). Précis de Parasitologie. (2nd ed.) Paris.

BüTschu, O. (1881). "Protozoa," in Zool. Jahresb.f. 1880. (1882). "Protozoa," in Bronn's Klass. u. Ordn. d. Tierreichs, I. (Sporozoa.)

Bulcoch, W. (1907). "Psorospermosis," in Allbutt and Rolleston's System of Medicine, Vol. II. Part 2, p. 825. London.

Cammidge, P. J. (1914). The faeces of children and adults. Bristol and London.

CAstellani, A. (1917). Notes on tropical diseases met with in the Balcanic and Adriatic Zones. Journ. Trop. Med. and Hyg. xx. 198.

CraGG, F. W. (1917). Observations on dysentery cases from Mesopotamia. Indian Journ. Med. Res. v. 301.

DARIER, J. (1889). De la Psorospermose folliculaire végétante, Ann. Dermatol. et Syphiligr. X. 597.

Davaine, C. (1860). Traité des Entozoaires. Paris.

Dickson, E. C. (1915). Oidiomycosis in California, with especial reference to coccidioidal granuloma. Arch. Intern. Med. xvi. 1028.

DOBELL, C. (1916). Incidence and treatment of Entamoeba histolytica infection at Walton Hospital. Brit. Med. Journ. II. 612.

(1917). Reports upon investigations in the United Kingdom of Dysentery Cases received from the Eastern Mediterranean. I. Amoebic Dysentery and the protozoological investigation of cases and carriers. Medical Research Committee, Special Report Series, No. 4. London.

Dogebul, C. and Stevenson, A. C. (1917). The Protozoological findings. Appendix to Medical Research Committee Special Report No. 5, p. 99. (Report upon 878 cases of bacillary enteritis, by L. Rajchman and G. T. Western.) London.

Doflein, F. (1901). Die Protozoen als Parasiten und Krankheilserreger. Jena.

- (1911). Lehrbuch der Protozoenkunde. III Aufl. Jena.

Eтmer, T. (1870). Ueber die ei- und kugelförmigen sogenannten Psorospermien der Wirbelthiere. Würzburg.

Evans, N. (1909). Coccidioidal granuloma and blastomycosis in the central nervous system. Journ. Infect. Dis. vI. 523.

Fantham, H. B. (1917). Some parasitic Protozoa of Man, and their probable evolution. Med. Journ. of South Africa, xmI. 33.

Finck, H. (1854). Sur la physiologie de l'épithélium intestinal. Thèse. Strasbourg. [Non vidi.]

GILES, G. M. (1890). A report on an investigation into the causes of the diseases known in Assam as kála-azár and beri-beri. Shillong.

Grassr, B. (1879). Intorno a speciali corpuscoli (Psorospermi) dell' uomo. Rendiconti $R$. Ist. Lombardo, Milano, xח. (2), 632. $(1879 a)$. Dei Protozoi parassiti e specialmente di quelli che sono nell' uomo. Gaz. Med. Ital. Lombard. (Milano), xxxrx. 445.

- - (1882). Intorno ad alcuni protisti endoparassitici, ed appartenenti alle classi dei Flagellati, Lobosi, Sporozoi e Ciliati. Atti Soc. Ital. Sci. Nat. xxIv. 135. 
Grassi, B. (1883). Sur quelques protistes endoparasites appartenant aux classes des Flagellata, Lobosa, Sporozoa et Ciliata. Arch. ital. Biol. II. 402, and III. 23.

(1888). Les protozoaires parasites de l'homme. Ibid. Ix. 4.

Grassi, B. and SchewiakofF, W. (1888). Beitrag zur Kenntnis des Megastoma entericum. Zeitschr. wiss. Zool. xLvi. 143.

Grunow, (1901). Ein Fall von Protozoen- (Coccidien?) Erkrankung des Darmes. Arch. f. exp. Pathol. u. Pharmakol. xLV. 262.

Gubler, A. (1858). Tumeurs du foie déterminées par des cufs d'helminthes et comparables à des galles, observées chez l'homme. Mém. Soc. Biol. Paris, v. (2 sér.), 61. (1858 a). Idem., Gaz. Méd. Paris, xIII. 657.

Haks, T. G. (1839). A treatise on Varicose Capillaries, as constituting the structure of carcinoma of the hepatic ducts, and developing the law and trentment of morbid growths. With an account of a new form of the pus globule. London.

Hartmann, M. (1912). “Demonstration eines neuen menschenpathogenen Protisten." (6 Tag. d. Freien Vereinig. f. Mikrobiol. in Berlin), in Centralbl. f. Bakt. I Abt. (Ref.), LIV. (Beiheft), 253.

Jolros, V. (1913). "Coccidiosen," in Kolle u. Wassermann's Handb. d. pathog. Mikraorg. 2 ed. vII. 711 . Jena.

JÜRGENS (1895). Ueber Erkrankung durch Protozoen beim Menschen. Berlin. klin. Wochenschr. xxxiI. 331 .

KLEBS(1859). Psorospermien im Innern von thierischen Zellen. Arch.f. pathol. A nal. xvr. 188.

Kunstlek, .J. and Pitres, A. (1884). Sur la présence de corpuscules falciformes dans le pus extrait de la cavité pleurale d'un malade atteint de pleurésie chronique latente. $C . R$. Soc. Biol. Paris, r. (8 sér.), 522.

- - (1884 a). Sur une psorospermie trourée dans une humeur pleurétique. Journ. de Microgr. Paris, vIIr. 469 and 520.

Labbé, A. (1893). Sur les Coccidies des Oiseaux. C. R. Acad. Sci. Paris, cxvr. 1300.

- (1896). Recherches zoologiques, cytologiques et biologiques sur les Coccidies. Arch. Zool. exp. IV. (3 sér.), 517.

- (1899). "Sporozoa," in Das Tierreich. Berlin.

Laveran, A. et Mesnil, F. (1902). Sur la coccidie trouvée dans le rein de la Rana esculenta et sur l'infection générale qu'elle produit. $C$. R. Acad. Sci. Paris, cxxxy. 82.

LÉGER, L. (1911). Caryospora simplex, coccidie monosporée, et la classification des Coccidies. Arch. f. Protistenk. xx匹. 71.

LeUCKaRT, R. (1863). Die menschlichen Parasiten, I. Leipzig u. Heidelberg. (1879). Die Parasiten des Menschen. 2 Aufl. I. Leipzig u. Heidelberg.

Lindmanan, C. (1863). Die Gregarinen und Psorospermien als Parasiten des Menschen. Bull. Soc. Imp. Nat. Moscou, XXXVI. (2), 425. (1865). Weiteres über Gregarinen. Ibid. xxxvIس. (2), 381.

LIPSCHÜTz, B. (1912). "Molluscum contagiosum," in Prowazek's Handbuch d. pathogen. Protozoen, 1. 219. Leipzig.

Low, G. C. (1918). A series of acute and sub-acute amoebic dysentery cases treated by emetine bismuth iodide and other drugs. Trans. Soc. Trop. Med. and Hyg. XI. 155.

LUCET, A. (1913). Recherches expérimentales sur la coccidiose du lapin domestique. $C . R$. Acad. Sci. Paris, cLVI. 1091.

LÜHE, M. (1902). Ueber Geltung and Bedeutung der Gattungsnamen Eimeria und Coccidium. Centralbl. f. Bakt. I Abt. (Orig.). xxxu. 771. (1906). "Die im Blute schmarotzenden Protozoen, und ihre nächsten Verwandten," in Mense's Handbuch d. Tropenkrankheiten (I Aufl.), III. 69.

Martin, C. J., KrllawaY, and Wilitams, F. E. (1918). Epitome of the results of the examination of the stools of 422 cases admitted to No. 3 Australian General Hospital, Cairo, for dysentery and diarrhoea-March to August, 1916 Journ. Roy. Army Med. Corps, $\mathrm{xxx} .101$.

Metzaner, R. (1903). Untersuchungen an Coccidium cuniculi. x Teil. Arch. f. Protistenk. II. 13 .

Minchin, E. A. (1903). "Sporozoa," in Lankester's Treatise on Zoology, Part I. fase. 2, p. 150. London. 
Mrnchin, E. A. (1907). "Protozoa," in Allbutt and Rolleston's System of Medicine, Vol. Ix. Part 2, p. 9. London.

(1912). An introduction to the study of the Protozoa. London.

Minchin, E. A. and FAnTHAM, H. B. (1905). Rhinosporidium kinealyi n.g., n.sp., a new Sporozoon from the mucous membrane of the septum nasi of man. Quart. Journ. Micro. Sci. XuIX. 521.

Pfeiffer, L. (1891). Die Protozoen als Krankheitserreger. (2 Aufl.) Jena.

Prok, L. (1895). Zur Protozoenfrage in der Gynäkologie. Berlin. klin. Wochenschr. XXXII. 472,504 .

Popwyssozk, W. (1889). Ueber die Bedeutung der Coccidien in der Pathologie der Leber des Menschen. Centralbl. f. Bakt. vı. 41.

- (1892). Berichtigung, die "Carcinom-Einschlüsse" und die "Krebs-Parasiten" betreffend. Ibid. XII. 551 .

Podwyssozki, W. and Sawtschenko, J. (1892). Ueber Parasitismus bei Carcinomen nebst Beschreibung einiger in den Carcinomgeschwülsten schmarotzenden Sporozoen. Ibid. XI. $493,532,559$.

Quincke, H. (1899). Ueber Protozoen-Enteritis. Berlin. klin. Wochenschr. xxxvI. 1001.

Ratllit', A. (1895). Traité de zoologie médicale et agricole. (2 ed.) Paris.

RAIlliet, A. and LuCET, A. (1890). Observations sur quelques coccidies intestinales. $C . R$. Soc. Biol. Paris, II. (9 sér.), 660.

- (1891). Note sur quelques espèces de coccidies encore peu étudiées. Bull. Soc. Zool. France, xvi. 246.

Raich, F. (1913). Das Kaninchencoccid Eimeria stiedae (Lindemann, 1865) nebst einem Beiträge zur Kenntnis von Eimeria falciformis (Eimer, 1870). Arch. f. Protistenk. XXVIII. 1 .

RIEck, M. (1888). Sporozoen als Krankheitserreger bei Hausthieren. Deutsche Zeitschr. $f$. Thiermed. XIV. 52.

Rivolta, S. (1873). Dei Parassiti Vegetali. Torino.

(1874). Sopra alcune specie di Tenie delle pecore e sopra speciali cellule oviformi dei villi del cane e del gatto. Pisa.

(1877). Delle cellule oviformi dei villi del cane. Studi fatti nel Gabinetto di Anatomia Patologica della R. Scwola Veterinaria di Pisa, p. 42.

- $(1877 a)$. Ancora delle cellule oviformi e specialmente di quelle con nucleo in segmentazione dei villi del cane. Ibid. p. 85.

- (1878). Della gregarinosi dei polli e dell'ordinamento delle gregarine e dei psorospermi degli animali domestici. Lombard. Giorn. d. Anat. Fisiol. e Patol. d. Anim. Pisa, Anni 1877-78, x. 220. Also reprinted as Studi fatti nel Gab. di Anat. Patol. della $R$. Scuola Superiore Veterinaria di Pisa, 1879 , p. 57.

Rixford, E. and Guchrist, T. C. (1896). Two cases of protozoan (coccidioidal) infection of the skin and other organs. Johns Hopkins Hosp. Rept. I. 209.

Rоснг, W. (1917). Intestinal Protozoa in Salonika War Area. Lancet, I. 297.

Sangrorar, G. (1918). Coccidiosi renale ed intestinale nell' uomo da "Isopora bigemina." Pathologica, x. 73.

Savage, R. E. and Young, J. R. (1917). Report on the treatment of fifty-nine cases of Entamoeba histolytica infection. Journ. Roy. Army Med. Corps, Xxix. 249.

SAwTschenko, J. (1892). Weitere Untersuchungen über schmarotzende Sporozoen in den Krebsgeschwïlsten. Centralbl. f. Bakt. xII. 17.

Schaddinn, F. (1900). Untersuchungen über den Generationswechsel bei Coccidien. Zool. Jahrb. Anat. Abt. xIII. 197.

Schneider, Aimé (1875). Note sur la psorospermie oviforme du poulpe. Arch. Zool. exp. Iv. Notes et Revue, p. xl.

(1881). Sur les Psorospermies oviformes ou Coccidies. Espèces nouvelles ou peu connues. Ibid. IX. 387.

SEebFR, G. (1912). Rhinosporidium Kinealyi et Rhinosporidium Seeberi, une question de priorité. La Ciencia Medica, Buenos Aires. [Separate.]

Silcock, A. Q. (1890). A case of parasiticism by psorospermia. Trans. Pathol. Soc. London, XLT. 320. 
PARASITOLOGY, VOL. XI. NO. 2

PLATE VIII
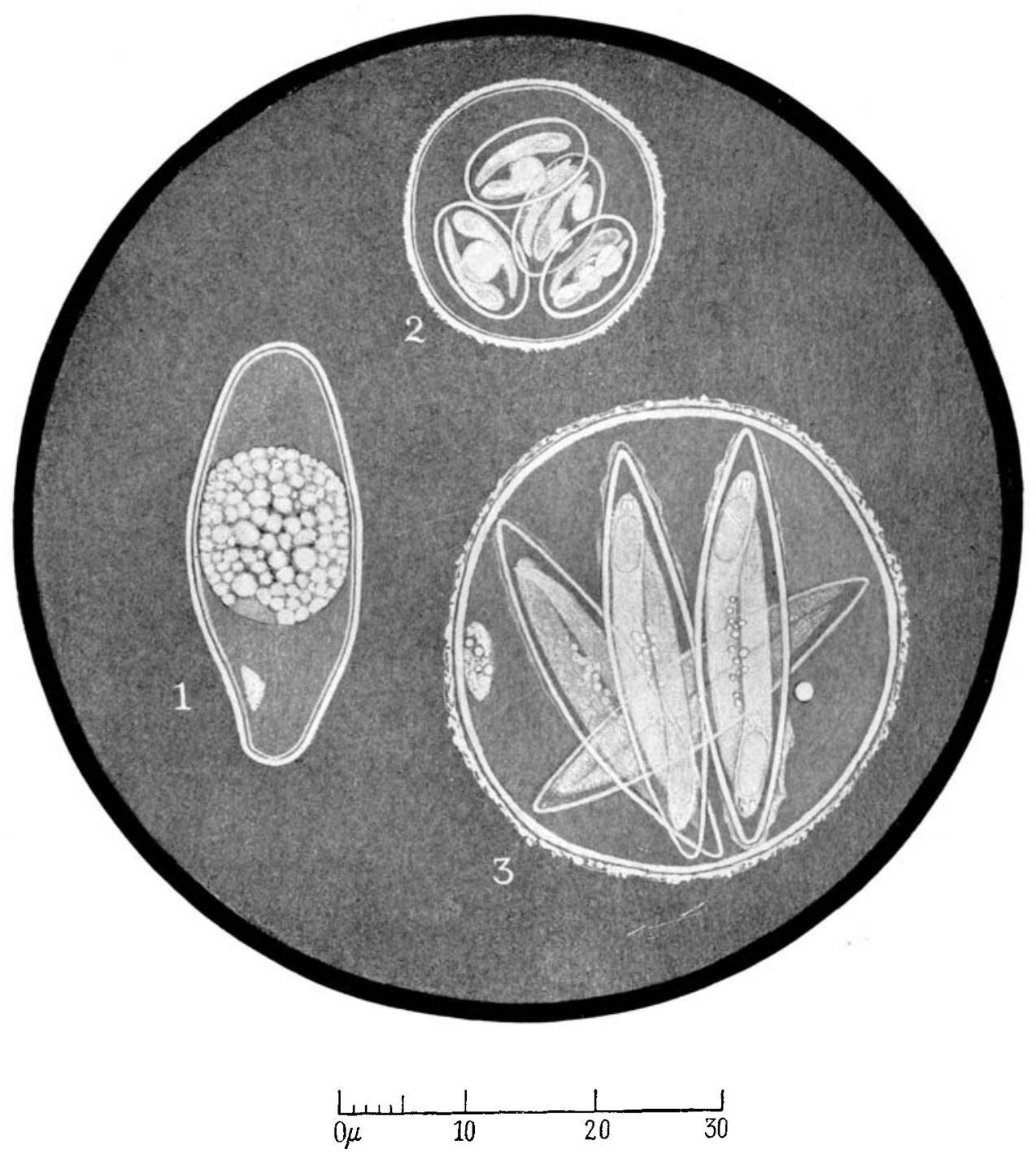

C. D. del.

Coccidia of Man 
Strkes, C. W. (1891). Note préliminaire sur quelques parasites. Bull. Soc. Zool. France, xvI. 163.

(1892). Notes on Parasites. 2. Journ. Comp. Med. and Vet. Arch. New York, Xmr. 517.

(1902). Eimeria stiedae (Lindemann, 1865), correct name for the hepatic coccidia of rabbits. U. S. Dept. Agric., Bur. Anim. Ind., Bull. xxv. 18.

Swellengrebel, 'N. H. (1914). Zur Kenntnis der Entwicklungsgeschichte von Isospora bigemina (Stiles). Arch. f. Protistenk. xxxu. 379.

Tномаs, J. J. (1899). A case of bone formation in the human brain, due to the presence of Coccidia oviformia. Journ. Boston Soc. Med. Sci. II. 167. Abstr. in Centralbl. f. Bakt. 1900 (I.), XXVIII. 882.

Virchow, R. (1860). Helminthologische Notizen. 4. Zur Kenntniss der Wurmknoten. Arch. f. pathol. Anat. XviII. 523.

Wenyon, C. M. (1915). Observations on the common intestinal Protozoa of man, their diagnosis and pathogenicity. Lancet, II. p. 1173.

- $(1915 \mathrm{a})$. The development of the oocyst of the human coccidium: an addendum. Ibid. p. 1296.

- $(1915$ b). Another human coccidium from the Mediterranean War Area. Ibid. p. 1404.

- $(1915 \mathrm{c})$. Observations on the common intestinal Protozoa of Man, their diagnosis and pathogenicity. Journ. Roy. Army Med. Corps, xxv. 600.

(1916). The protozoological findings in five hundred and fifty-six cases of intestinal disorder from the Eastern Mediterranean War Area. Ibid. xxvi. 445.

Wenyon, C. M. and O'Connor, F. W. (1917). An inquiry into some problems affecting the spread and incidence of protozoal infections, etc. Part II. Ibid. XxVIII. 346.

Wernicke, R. (1892). Ueber einen Protozoenbefund bei Mycosis fungoides (?). Centralbl. f. Bakt. XII. 859.

Wolbach, S. B. (1904). The life-cycle of the organism of "dermatitis coccidioides." Journ. Med. Res. XIII. 53.

Woodcock, H. M. (1915). "Notes on the protozoan parasites in the excreta," appended to paper by Ledingham and Penfold: Recent bacteriological experiences with typhoidal disease and dysentery. Brit. Med. Journ. It. p. 704.

Woopcock, H. M. and Penfold, W. J. (1916). Further notes on protozoan infections occurring at the King George Hospital. Ibid. I. p. 407.

ZüBLIN, E. (1908). Beitrag zur Kenntnis der roten Ruhr des Rindes. Schweizer Arch. $f$. Tierheilk. f. 3, p. 123.

\section{DESCRIPTION OF PLATE VIII.}

The figures in this Plate show the oocysts of the three human intestinal coccidia described in the text. They were all drawn originally at a uniform magnification (approximately 2000 diameters), and have been reduced to the size here shown (1600 diameters) in the process of repro. duction. Figs. 1 and 3 were drawn, under a $2 \mathrm{~mm}$. apochromat (N.A. =1.40), from living oocysts. Fig. 2 is copied, with very slight modification, from Wenyon $(1915 b)$. The oocysts are shown as they usually appear in freshly passed human faeces-those of the two species of Eimeria containing fully formed spores, that of the Isospora with its contents still unsegmented. (The fully developed oocyst of this species, containing two tetrazoic spores, is shown in Text-fig. 1, B, p. 177.)

Fig. 1. Isospora hominis Rivolta (emend.). Undeveloped oocyst.

Fig. 2. Eimeria wenyoni n.sp. Fully developed oocyst and spores.

Fig. 3. Eimeria oxyspora n.sp. Fully developed oocyst and spores. 